Artigos

\author{
Licia Fiol-Matta \\ Lehman College, City University of New York
}

\title{
"Mulher-raça": a reprodução da nação em Gabriela Mistral
}

\begin{abstract}
Resumo: O artigo desmascara a posição pública assumida por Gabriela Mistral como defensora dos povos indígenas, argumentando que no âmbito privado sua posição foi absolutamente oposta a qualquer afirmação sexual pública não-normativa. A autora sugere três operações críticas para a leitura da obra de Mistral sobre o sujeito da "raça" latino-americana: a recusa da negritude (Mistral reage a ela com ansiedade, sexualização e patologização, ou seja, com atitudes brancas estereotipadas), a cumplicidade da linguagem da diversidade com as práticas do pensamento supremacista branco (evidenciada em sua correspondência) e o papel da queerness no nacionalismo racializado de Mistral (sua atitude queer acabou ajudando a aprimorar a heteronormatividade e o projeto racial latino-americanista).
\end{abstract}

Palavras-chave: Gabriela Mistral, queer, normatividade sexual, raça, povos indígenas.

Copyright (c) 2005 by Revista Estudos Feministas

\footnotetext{
'Race woman, termo tomado de empréstimo dos estudos afroamericanos, que se refere à muIher militante que abraça e defende a raça. Freqüentemente suas ações e seus textos se adaptam aos padrões normativos que definem a raça, pressupondo um discurso de gênero conservador e heteros-sexualizado. Algumas vezes a mulher-raça pode ser mais crítica em relação ao sexismo das lideranças masculinas correspondentes.
}

A poeta, educadora e prêmio Nobel chilena Gabriela Mistral (1889-1957) é um exemplo de intelectual queer latino-americana que através de seu discurso nacionalista se tornou útil à instituição de uma normatividade sexual e racial. Este artigo amplia o alcance do debate sobre a identidade sexual de Mistral examinando sua condição de "mulher-raça" ["race woman"], uma posição pública que ela estabeleceu com ímpeto, e que é oposta a qualquer afirmação sexual pública não-normativa. ${ }^{1}$

Para o público latino-americano, Mistral assumiu a matriz heterossexual. Mas sua queerness estava mesmo completamente fora da visão pública? Certamente Mistral aludia à sexualidade reprodutiva toda vez em que falava de raça. Ela consistentemente retratava-se como spokesperson da América Latina - referindo-se à "nossa raça" - posando de mãe mestiça da nação. Mistral dedicou muitos textos ao tema de uma cultura unificada latinoamericana, alcançada através de processos de reprodução individual e social. Conhecida por sua defesa 
dos povos indígenas da América Latina, ela freqüente e vigorosamente aludia ao processo de mestiçagem.

Através da posição de "race woman" Mistral ajudou - Estado a administrar as populações racialmente heterogêneas da América latina, tidas como problema desde as guerras de independência. Tanto no âmbito público quanto no privado ela se ocupou de assuntos que variaram da classificação e ordenação hierárquica das "misturas" raciais ao status de negros latino-americanos no discurso nacionalista, da mestiçagem desejável no território latino-americano à mestiçagem perigosa para além da vigilância atenta do Estado.

É tentador separar as identidades sexual e racial em Mistral, considerando uma como privada e a outra como pública, uma secreta e outra em estridente exposição. Normalmente um dilema como o de Mistral costuma ser analisado em partes: uma identidade por vez. A história de sua vida romântica é separada daquela de sua carreira pública, e até sua figura pública se desdobra de acordo com a narrativa da maternidade republicana. Uma atenção indiscreta aos detalhes inventados de sua existência privada casa alegremente com uma visão hagiográfica de seu papel em assuntos internacionais. Mas para entender a complexidade de Mistral mais amplamente, torna-se útil examinar suas identidades pública e privada menos como blocos distintos e mais como entrelaçadas e interdependentes.

Examinar a interseção entre raça e sexualidade em Mistral é fundamental em mais de um sentido. Desfazer mitos sobre ela é importante, mas entender toda uma mitologia colocada a serviço do Estado é crucial. Tanto a mistura racial (sexualidade coletiva) quanto a sexualidade ambígua de Mistral (vista como assunto privado) envolvem a demarcação social entre o sexo aceitável e o inaceitável; nas duas instâncias, o sexo é codificado como reprodução. No projeto de Estado que Mistral ajudou a articular, a reprodução significava não só maximizar os corpos das mulheres no sentido de produzir trabalhadores fortes e administrar famílias produtivas, patriarcais e heterossexuais, mas também estabelecer e reforçar os parâmetros sobre quem pertence à nação, racialmente falando. Essa é a verdade sobre o sentido restrito de Estado-nação emergente - o que é ser um chileno? quem pode ser considerado um mexicano? - e sobre o sentido expansivo, massivo mesmo, do latino-americanismo. Reforçar a estrutura do pertencimento envolvia um papel subterrâneo, mas não menos forte para a sexualidade "silenciosa" de Mistral. Como já discuti em outro texto, a fala sobre reprodução e cuidado com a infância funciona como um closet que 
2 Licia FIOL-MATTA, 1995, p. $201-$ 229.

\footnotetext{
${ }^{3}$ Elizabeth Rosa HORAN, 1997, discute uma fusão entre o corpo de Mistral e a nação. Horan trata da monumentalização da figura de Mistral após sua morte através de escultura pública, moeda e afins.
}

${ }^{4}$ MOLLOY, 1998, p. 142. paradoxalmente tornou público o que era para permanecer privado. ${ }^{2}$ No contexto mais amplo da sexualidade pública ou coletiva, Mistral usa a mesma linguagem para estabelecer uma linha firme e muitas vezes onerosa para definir o pertencimento à nação. Estabelecer a conexão entre sua queerness e o discurso racial que ela adotou com sucesso é o objetivo deste artigo.

Uma análise intersecional revela que a heterossexualidade simbólica de Mistral se prestou a garantir ou beneficiar, não a heterossexualidade per se (isto é, não a todos os heterossexuais, indistintamente), mas uma heterossexualidade específica, concebida para o projeto do Estado. Mistral ofereceu seu próprio corpo como representação de toda uma raça - uma raça criada a partir de uma tradição inventada. ${ }^{3}$ Mas como uma mulher que não deu à raça filhos biológicos, e que andava sempre junto com mulheres, pôde se tornar o símbolo duradouro da mãe nacional? Sua sexualidade vivida não coincidia com a prescrição nacional, mas sua queerness era o grande trunfo de sua pose relativa ao nacional?

Em The Politics of Posing, Sylvia Molloy classifica a adoção dessa pose queer latino-americana como perversa, tal como a adoção de uma atitude efeminada ou sodomita diante das masculinidades prescritivas. Ao expandir o conceito de pose para incluir poses como a de Mistral, este artigo articula uma noção de exposição mais próxima à de dispositivo. Molloy discute a pose da queer como um tipo de resistência sexual e de gênero a uma ideologia nacionalista prescritiva:

quero pensar diferente sobre a pose na América Latina não como a atitude óbvia e sem-graça de certas fêtes galantes fantasmagóricas, um punhado de afetações corporais ou textuais em conflito com discursos e preocupações nacionais e continentais dos quais a América Latina vem se recobrando ultimamente, mas como uma prática de oposição e uma afirmação cultural decisiva cujo valor político e cuja energia desestabilizadora vou tentar recuperar e avaliar. ${ }^{4}$

Mistral assumiu uma pose aberta e direta, como mãe, como mestiça, mas essa pose encorajou - em vez de desestabilizar - o discurso nacional. De fato, posar faz parte da efetividade do nacionalismo, já que envolve a complicada questão da identificação. Latino-americanos conservadores devem ter sentido que suas identidades como sujeitos nacionais não sofreram qualquer ameaça com a ascensão de uma mulher queer como Mistral, mas o problema vai além. Como estabeleceu Foucault, o poder assume a mais fraca de suas condições quando não faz mais do que negar. A figura de Mistral possibilitou aos 
5 Para um estudo mais extenso desse fenômeno em Mistral, ver FIOL-MATTA, no prelo.

${ }^{6}$ MOLLOY, 1998, p. 150 e 151
${ }^{7}$ MISTRAL, 1992, p. 100. Grifo meu. cidadãos tornarem-se parte da natureza produtiva do poder, especificamente através dos prazeres da identificação prazeres que com certeza sustentaram diferentes ações, tanto as liberacionistas quanto as repressivas. ${ }^{5}$ Não era simplesmente uma pose pro patria, do tipo que Molloy observa no Ariel de José Enrique Rodó - uma pose construída para esconder um desejo homoerótico, visível apenas no momento em que Próspero acaricia a estátua de bronze de Ariel e "descobre Rodó". 6 O exemplo de Mistral fornece um modelo para a incorporação da queerness no projeto de Estado e deixa claro que a queerness latino-americana não era assim tão invisível quanto se podia considerar.

É no mínimo paradoxal e extraordinário que Mistral tenha obtido o status de guardiã simbólica da família nacional. Tivesse ela escolhido enfatizar sua inconstância publicamente - sua masculinidade, suas escolhas na organização de sua vida íntima, seu fracasso em casar e ter filhos - sem alçar o jogo de identificação a uma escala nacional e transnacional, o Estado, com seus amplos recursos, teria massacrado suas ambições. O Estado, porém, foi atraído por sua queerness, por aquilo que ela, e só ela, pôde conseguir no reino biopolíico de poder. Assim a união foi consumada: Mistral apareceria na esfera pública como a grande estrela do Estado, posando como alguém que, de tão ligada à causa nacional, sacrificou suas mais caras aspirações pessoais para o bem dos "filhos da nação", os dela e os do Estado, ou seja, para o bem dos cidadãos.

Mistral quase sempre planejou e executou sua participação na agenda do Estado. Considere sua declaração sobre seu próprio potencial, bem como sobre sua atenção, intensamente voltada para si mesma, em uma carta de 1923 a Pedro Aguirre Cerda:

\begin{abstract}
de todas as nações latino-americanas, o Chile é a que menos se esforça para fazer propaganda no exterior. Ele não se importa com sua imagem, ou então acredita que apenas ministros e cônsules possam gerar essa propaganda; mas estes ficam apenas na boa vida e não divulgam as coisas do Chile. Acredito poder fazer o que eles ainda não fizeram, e poder fazê-lo com as únicas ferramentas da propaganda efetiva: as escolas e a imprensa. $^{7}$
\end{abstract}

Sem dúvida a noção quase mercenária de cultura de Mistral carrega um bocado de autoproteção. No entanto, poderia essa noção ter excedido as exigências da autoproteção? Além disso, faria ela algum sentido para além de uma deliberada autopromoção? Mistral identificava-se com o projeto nacional?

Em 1918 Mistral foi enviada a Magalhães, a província mais ao sul do Chile, com uma missão específica, chilenizar: 
${ }^{8}$ Roque Esteban SCARPA, 1977, v. 1, p. 18. Sobre chilenizar, ver também Volodia TEITELBOIM, 1991, $p$ 87.

${ }^{9}$ Atos organizados de protesto in cluíram a revolta de trabalhadores de Puerto Natales e Punta Arenas em 1919 e 1921, respectivamente. O Estado reprimiu violentamente as duas manifestações, massacrando igualmente trabalhadores e pessoas indígenas. Mistral foi alocada em Punta Arenas durante a primeira revolta $e$ já havia deixado a região na época da segunda. Ver TEITELBOIM, 1991, p. 87-91.

${ }^{10}$ Ver o prefácio de Mistral para SCARPA, 1977, p. 11-25. Esse prefácio foi escrito quase três décadas depois de Mistral ter saído de Magalhães. É possível que Mistral, ao saber da intenção de seu amigo de compilar um livro sobre seus primeiros anos no Chile, tenha pensado em influenciar sua recepção e moldar a percepção pública de sua estada em MagaIhães. Ela insistiu em escrever 0 prefácio. "eu tive que chilenizar sua terra natal [a de Roque Esteban Scarpa], por ordem de meu ministro e amigo". ${ }^{8}$ Essas afirmações, conjugadas com o conhecimento de grandes atos de protesto contra o Estado, comuns à época, revela muito sobre o projeto racial do Estado: ${ }^{9}$ assimilar ou aniquilar populações indígenas na província, promover a imigração do norte da Europa para "branquear" a raça no Chile (Mistral menciona iugoslavos e alemães no mesmo texto) e simbolicamente implantar a idéia da lealdade dos cidadãos à nação chilena, visando mais especificamente às classes trabalhadoras. Mistral falava com rancor sobre sua estada em Magallanes, se bem que as mesmas prerrogativas nacionais que ela às vezes rejeitava com veemência tenham orientado seus discursos público e privado até sua morte. Embora Mistral insinuasse perplexidade quanto a seu papel nessa empreitada, ela o internalizou e o viveu plenamente, a ponto de seus próprios sentimentos se mesclarem no projeto racial do Estado. ${ }^{10}$

A preocupação de Mistral com as fronteiras nacionais tornou-se obsessiva em seus discursos e práticas raciais. Nesse sentido, ela (e o Estado) praticaram uma espécie de profilaxia social. Mas uniram as práticas individuais e sociais dessa profilaxia a tal ponto que elas foram experimentadas como uma coisa só. Quando lido através das lentes da raça, o discurso mistraliano não é "pessoal", como sua tão propalada, mas não muito convincente, fábula autobiográfica nos faria acreditar. Mistral aparece como alguém diferente da mulher e esposa frustrada que nunca encontrou outro amor capaz de se equiparar ao primeiro romance, ou, de maneira mais crucial, como a defensora incondicional de todas as crianças, todas as mães e todas as "minorias" raciais.

Pode-se dizer que Mistral foi movida por um desejo de se erigir como um pilar em discursos de apelo às massas, e como uma atriz das transformações que ocorreram em parte pela ativação desses discursos. Suas duras experiências relativas a gênero e sexualidade, embora muito reais, não compensaram a maturação de uma identificação racial anterior com o Estado-nação. De fato, seu "segredo revelado" interagiu com sua identificação ao projeto racial chileno e com sua desmedida ambição de ancorar o Estado racial. É fundamental perceber que a identificação racial de Mistral não foi reflexo de sua personalidade única; o tratamento que ela dedica aos outros racializados e à mestiçagem pode às vezes parecer idiossincrático, mas ela própria acabou sendo construída por conta do projeto racial, ao mesmo tempo que deu forma a ele ao se tornar sua ativa enunciadora. Identificações raciais coletivas em fluxo - experimentadas pela maioria 
"Para vários relatos dessa preocupação disseminada com a mistura racial "certa ou errada", ver Nancy Leys STEPAN, 1991; Richard GRAHAM, 1990; e Thomas E. SKIDMORE, 1993

${ }^{12}$ Veja também a brilhante análise das aulas de Foucault feita por Ann Laura STOLER, 1995.

${ }^{13}$ Ana PIZARRO, 1997, p. 49. dos cidadãos latino-americanos durante o período de uma modernização desigual - foram refratadas unicamente através de Mistral, fortalecendo-se rumo a uma identificação nacional comum, costurada de acordo com o desejo do Estado.

\section{Mestiçagem e queerness}

Mistral é normalmente saudada como a grande defensora das populações indígenas da América Latina, particularmente dos mestiços. A mestiçagem, como aparece neste ensaio, não é uma mistura racial espontânea, ditada por movimentos e contatos entre populações, mas um fenômeno sustentado e administrado pelo Estado. A mistura racial foi toda uma arena de políticas e práticas discursivas, exigindo classificação, perícia e vigilância. ${ }^{11}$ As aulas de Foucault no Collège de France, em 1976, sobre a genealogia do racismo, especificamente sua noção da violência do biopoder, são perfeitamente adequadas a essa discussão. De acordo com Foucault, a violência do biopoder tem menos a ver com atos de matança do que com exclusões institucionalizadas e hierarquias desenhadas para garantir que somente alguns tenham a "capacidade de viver" em uma sociedade normalizadora. ${ }^{12}$ Uma genealogia foucautiana da mestiçagem no trabalho de Mistral - uma tentativa de definir condições para sua emergência, e também de localizá-la - indica que ela tomou esse conceito diretamente de José Vasconcelos e do grande projeto de construção de nação após a Revolução Mexicana. Além disso, tal genealogia também sugere claramente que para Mistral a mestiçagem significou essencialmente a articulação de uma noção cultural de "unidade" a serviço de uma agenda integracionista.

A mestiçagem implica um binarismo que marginaliza latino-americanos e descendentes de africanos. Na melhor das hipóteses, estes são folclorizados como uma minoria "exótica"; na pior, são literalmente eliminados. Mas antes de explorar mais amplamente o tratamento dado ao sujeito negro latino-americano, é conveniente revisitar uma questão crítica no discurso racial de Mistral: o caráter de sua "defesa" das populações indígenas.

Por mais que pareça chocante hoje, a jovem Mistral foi atraída pela crença na supremacia branca. Ana Pizarro relata que já no início da carreira, nos feriados em que se comemorava o Dia da Raça, Mistral falava da "salvação do branco" e da "pureza da raça". ${ }^{13}$ Curiosamente ela só abandonou seu discurso virulento e começou a falar em nome das populações indígenas depois de sua primeira visita ao México em 1922, quando Vasconcelos a convidou 
14 Pizarro percebe também que Mistral mudou sua postura supremacista depois de sua visita ao México em 1922, mas sobre isso nossos pontos de vista divergem. Pizarro escreve: "o olhar de Mistral muda no México, é claro, e esse novo olhar se reafirma no Brasil, numa época em que Gilberto Freyre e Sérgio Buarque de Holanda empreenderam uma releitura fundamental da cultura negra" (PIZARRO, 1997, 49). Freyre e Buarque de Holanda fizeram parte de uma tendência à normalização e contribuíram com o que Foucault chamou de "governamentalidade". Em relação aos negros, a visão racista de Mistral permaneceu a mesma. Se houve alguma mudança, fol ter-se tornado mais sanguinária. Suas referências ao Brasil cristalizaram justamente esse racismo perigoso.

${ }^{15}$ Quezada também atribui a decisão de Mistral de defender povos indíigeas a sua missão no México, mas ele insiste: "essa abordagem das verdades dos índios teria começado mesmo em 1919, em seu exílio em Magallanes" (QUEZADA, 1994, p. 12) como parte de suas reformas educacionais. Mas essa mudança era sincera e humanitária, ou uma adoção estratégica de um discurso de normalização? Pizarro acredita na primeira opção. ${ }^{14}$ No mínimo, a mudança de Mistral foi impecavelmente oportuna.

O primeiro dos ministros da educação do México moderno, Vasconcelos foi o primeiro empregador internacional de Mistral. Seu convite aumentou substancialmente nela o sentimento de poder pessoal sobre as políticas culturais da época, e pode-se argumentar que ela tenha percebido em sua defesa das populações indígenas uma oportunidade. Jaime Quezada acredita que Mistral mudou de idéia em Magalhães, ou seja, antes de deixar o Chile. Mas não há textos pedagógicos do período que glorifiquem o indígena ou o mestiço no Chile. Quezada baseia-se nos textos que Mistral escreveu em 1932 e 1948, que na verdade mostram o quanto ela aprimorava seu passado chileno e seu papel na chilenização do país. O modelo de administração racial do Chile encontrava-se claramente na Argentina, seu vizinho de Cone Sul, não no México populista. ${ }^{15}$ Aguirre enviou Mistral a Punta Arenas para dirigir uma escola de meninas. Escolas de meninas eram dirigidas a filhas privilegiadas da burguesia nascente, não a filhas de trabalhadores, e certamente não a filhas de populações indígenas. Enviada à região mais propriamente indígena do Chile, e também a mais afetada pela imigração, para dirigir uma escola de "verdadeiras" mulheres nacionais, Mistral supostamente evitaria qualquer risco de promiscuidade sexual. Como aponta Jorge Salessi, na Argentina uma sofisticada literatura pedagógica e criminológica abordou os "perigos" do lesbianismo (chamado "fetichismo" e "uranismo") no mundo homo-social das escolas de meninas. Essa tarefa de Mistral teria sido mera ironia histórica?

Sua consciência de seu alto prestígio depois da visita ao México colaborou com o tom autoritário de sua carta para Aguirre citada acima. Sua visita ao México tem também íntima relação com um detalhe interessante. Vasconcelos tinha atração por ela devido a sua queerness, rejeitando outros modelos de femininidade que ele poderia ter importado do Cone Sul. Em uma alegre confidência a seu amigo Radomiro Tomic, Mistral comenta a impressão que sua imagem causou em Vasconcelos no México:

basta-me, eu te asseguro, estar em pé de igualdade com os outros cônsules, apesar de ser mulher. Isso seria suficiente, repito. Vou voltar no tempo para esclarecer os fatos a você. [O presidente Arturo] Alessandri disse a Vasconcelos, quando eu estava no México, que este havia cometido um grande erro trazendo ao México Gabriela Mistral em vez de 
${ }^{16}$ Luis Vargas SAAVEDRA, 1995, p. 102.
17 Discuto isso de modo mais aprofundado em FIOL-MATTA, no prelo.

${ }^{18}$ MOLLOY, 1998, p. 154.
[Amanda Labarca Hubner]. E num banquete, depois disso, Alessandri apresentou Mistral a Vasconcelos e a fez sentar perto dele. Quando Alessandri se levantou para sair, Vasconcelos disse a ele: "dessas [como Hubner] nós temos muitas no México; demais na verdade. Mas essa que eu trouxe comigo [Mistral] é diferente e queer". Ele riu ao me contar isso. ${ }^{16}$

Quando Mistral conta esse episódio, ela e Vasconcelos estão compartilhando uma piada secreta. Sua confiança em seu "amigo" Tomic coloca esse relato diretamente no reino do discurso pessoal, mas Mistral é bem clara quanto às conseqüências de sua queerness para suas chances de uma vida pública em um mundo de homens. A comparação com Amanda Labarca Hubner, talvez a feminista chilena mais importante da época, é inequivocamente favorável ao desdém que Mistral, e talvez também Vasconcelos, mostrava pela prevalência da imagem pública da mulher. Essas feministas não se adequariam a uma imagem transnacional, ou ao papel de porta-voz. Elas nunca provocariam o ilimitado fascínio que Mistral evidentemente se sentia capaz de provocar. $O$ testemunho de muitos de seus contemporâneos confirma que essa impressão não era falsa e reforça a evidência de que sua "masculinidade" em muito colaborou com essa atração. ${ }^{17}$

Vasconcelos estava em busca de um ícone incomum - uma mulher descentrada. O que ela representava, para ele, não era "um grande alívio cultural, parecido com o 'não temos disso por aqui' de certas construções de nacionalidade angustiantes", mas exatamente 0 oposto. ${ }^{18}$ Vasconcelos finalmente achou a forma corporal da femininidade que ele queria. Queerness é aquilo que o México não tinha, e aquilo de que supostamente precisava. Evidentemente, Vasconcelos pensou que precisava incorporar a queerness para que seu esforço educacional nacionalista funcionasse. Aí se encontra seu brilhantismo perverso; sendo um homofóbico de primeira ordem, ele contratou intelectuais e escritores gays e lésbicas proeminentes para dar suporte a sua reforma educacional. A efetividade dessa tática sensibilizou também Aguirre, mas Vasconcelos parece ter tido uma visão muito mais sofisticada. Ele viu que havia algo desprezado na queer que podia estar ligado ao outro racializado, igualmente desprezado, algo sobre a inclusão da queer como um ser solitário e inacessível que poderia fazer avançar a inclusão simbólica das populações indígenas nos mesmos termos.

Naturalmente, Mistral explorou a lição regional do México. Tendo em mente, com convicção, a visibilidade internacional que a Revolução Mexicana havia atingido, 
19 Mistral escreveu essa carta no dia 2 de outubro de 1918, de Punta Arenas (ver SCARPA, 1977, v. 2, p. 333).

${ }^{20}$ MORALES, 1980.
21 Quando Mistral tinha 25 anos de idade, por exemplo, ela se descreveu como "esta buena vieja que hace versos" (Isauro SANTELICES, 1972, p. 73). ela criou uma autêntica pedagogia transnacional. Sua reivindicação por uma "propaganda" maior em favor do governo chileno reflete uma mudança importante em relação à atitude que demonstrava nas cartas a Aguirre quando era ainda uma desconhecida professora de escola nas províncias do Chile. Nessas cartas Mistral submetia-se plenamente a ele, vendo nele "o comandante": "para mim, ministro, você será sempre a autoridade intelectual e espiritual cujo credo pedagógico espero um dia tornar realidade, a fonte da aprovação que mais me satisfaz e da censura que mais me entristece". ${ }^{19}$ Ela percebeu que precisava de um protetor homem agindo em seu nome para assegurar aquilo a que Juan Villegas Morales deu o nome de papel do Estado como mecenas. ${ }^{20} \mathrm{O}$ que a jovem Mistral não compreendeu plenamente antes de 1922 foi o potencial de sua queerness. Mesmo sabendo que seu considerável talento literário a resgataria de um ambiente chileno sufocante, Mistral queria mais. Ela se identificou com o poder e foi atraída por ele. Apesar de sua postura de defensora das populações indígenas, Mistral era branca e identificada como tal, o que parcialmente explica o fato de sua pose de mestiça ser encarada como queer. Seu discurso racial ao mesmo tempo autoriza e desautoriza sua queerness.

A feiúra que Mistral reconhecia em si mesma, sua pose de alguém que se odeia e age sem pensar, assume um caráter totalmente diferente quando justaposta a sua excessiva identificação com o "índio", universalmente reconhecida. ${ }^{21}$ As duas poses têm semelhanças surpreendentes. Talvez Mistral tenha tido de fato sentimentos profundos em relação ao índio e ao mestiço. Certamente ela levou a sério sua identificação cruzada com eles. Mais importante, essa identificação - que é queer - teve uma dimensão política e social de valor histórico inestimável. Mistral incorporou a imagem pedagógica do índio e do mestiço. Graças a ela, essa imagem chegou às escolas da América Latina. Os ensaios "A la mujer mexicana" e "El tipo del indio americano", altamente antologizados, quando examinados rapidamente, são meros exemplos da disseminação dessa imagem.

Mistral ofereceu uma fábula atraente: um objeto bonito confundido com um feio, um ícone milenar e singular fatalmente apartado da vida social, uma estranheza merecedora de uma curiosa combinação de admiração e pena. Essa narrativa mostrou como foi possível amar e desprezar o outro, além de amar e desprezar a si mesma. Mistral encorajou a identificação de cidadãos latinoamericanos com essa imagem de pessoa da terra; encorajou também, através de sua figura queer, sujeitos 
22 Para uma lúcida explicação desses termos psicanalíticos, a partir da perspectiva queer, ver Diana FUSS, 1995.

${ }^{23}$ OMI e WINANT, 1994, p. 67.

${ }^{24}$ MISTRAL, 1978a, p. 179. nacionais a se fecharem em um jogo psicológico com o Estado-nação. Identificação, identificação cruzada e contra-identificação tornaram-se os principais exercícios de cidadania. ${ }^{22}$

Enquanto sua auto-apreciação como feia coincidia com sua glorificação do indígena como bonito, Mistral concentrou-se, nas décadas de 20 e 30 , na classificação do corpo indígena. Apesar de ter lecionado desde 1914 e de ter escrito regras de comportamento para professores de escola, além de peças elogiosas ao sistema de ensino público, Mistral escreveu seus mais vigorosos textos sobre educação uma década depois. Eles revelam sua preocupação com a "nossa raça"; tomando emprestada uma expressão de Michael Omi e Howard Winant, o "senso comum racial" permeou seu trabalho até sua morte. ${ }^{23}$ Considere-se um trecho de "El tipo del indio americano" (1932):

uma das razões da repugnância nativa pela confissão da presença índia em nosso sangue, uma das origens de nosso medo de contar ao mundo que somos mestiços leais, é a chamada feiúra do índio. Assumimos isso como uma verdade irrefutável; aceitamos isso sem questionar. Isso aparece lado-a-lado com expressões como "o índio é preguiçoso" ou "o índio é mau".

[...] Devíamos ter ensinado nossas crianças sobre a beleza diferenciada e oposta das raças. Um olho comprido e fino é bonito no mongol, mas deprecia um rosto caucasiano. Uma cor amarelada, variando de um tom de palha ao da pele de um carneiro, acentua a delicada natureza do rosto chinês. No europeu ela sugere um sangue depauperado. Cabelos encaracolados são uma coroa gloriosa na cabeça do caucasiano; no mestiço eles sugerem algo do mulato, e então preferimos as lisas madeixas do índio. ${ }^{24}$

Para além da interpretação racial da beleza nesse ensaio, Mistral analisa misturas raciais em termos binários, considerando vantagens e desvantagens. A oposição binária beleza/feiúra e a idéia vasconceliana de "seleção estética" orientam todos os seus escritos depois de 1922 e bem podem ser interpretadas como subtexto de sua subseqüente autocaracterização como índia ou mestiça, cada vez mais freqüente e altamente problemática. Sua transformação racial, produzida no discurso, era tão profunda que se tornou lugar-comum na esfera pública a referência a Mistral como mestiça. Seus biógrafos e críticos assumiram essa identificação como fato biográfico, o que persiste até hoje. A negação feita por Mistral da "chamada feiúra do índio" é geralmente lida como uma defesa do "elemento índio" na configuração racial do sujeito latino-americano universal. Em um arguto ensaio sobre Mistral e Victoria 
${ }^{25}$ KAMINSKY, 1993, p. 118-119 e 121

\begin{abstract}
${ }^{26}$ Embora eu isole Vasconcelos, ele não foi o único a praticar a ideologia da mestiçagem, muito menos seu autor. Para uma introdução à genealogia desse mo delo no México, ver Alan KNIGHT, 1990.

27 "Definimos formação racial como o processo sócio-histórico pelo qual categorias raciais são criadas, ocupadas, transformadas e destruídas"; "propomos formação racial como um processo envolvendo projetos historicamente situados nos quais corpos humanos e estruturas sociais são representados e organizados"; "projetos raciais desenvolvem o 'trabalho' ideológico de construir essas ligações. Um projeto racial é simultaneamente uma interpretação, representação ou explanação da dinâmica racial e um esforço para redistribuir recursos de acordo com linhas raciais específicas" (OMI e WINANT, 1994 p. 55-56)
\end{abstract}

${ }^{28}$ VASCONCELOS, 1996, p. 42-43. Grifo meu. Agradeço a Julio Ramos me chamar a atenção para esse trecho.
Ocampo, Amy Kaminsky reconhece o uso problemático que Mistral faz dos estereótipos ao desenhar um índio simbolicamente bonito; seu famoso ensaio "Silueta de la india mexicana", de 1923, por exemplo, "faz pouco mais do que trazer a índia para o campo de visão e transformála num objeto de beleza". ${ }^{25}$ Kaminsky acredita, porém, que Mistral, em essência, de fato se importou com as populações indígenas, e que ao assumir essa causa ela se tornou uma outsider social. Mas essa não parece uma leitura superficial? É vital contextualizar a "defesa" feita por Mistral e desvelar o lugar de onde a idéia de feiúra surgiu. Para revelar o que essa defesa possibilita - ou pelo menos o problema que ela desconsidera - é útil primeiro ponderar a considerável influência de Vasconcelos. ${ }^{26}$

Em seu tratado La raza cósmica, de 1925, Vasconcelos apresenta uma verdadeira narrativa excepcionalista, colocando a América Latina diretamente no centro dos assuntos internacionais através de uma construção racial, ou, nas palavras de Omi e Winant, de um projeto racial. ${ }^{27} \mathrm{~A}$ mestiçagem, propõe Vasconcelos, constitui a especificidade racial da América Latina, bem como sua vocação para a centralidade. Essa região, por si só, contém as quatro raças do mundo, o que significa que a próxima (e para ele a última) raça líder - a quinta raça, ou raça cósmica - vai nascer na América Latina. Curiosamente, o processo de miscigenação não é aleatório; é meticulosamente seletivo. Em um trecho altamente questionável mas fascinante, Vasconcelos prevê que "raças feias" vão "sair de circulação" voluntariamente, a partir do princípio de "eugenia estética", ou do critério de "gosto".

Os tipos inferiores da espécie vão ser absorvidos pelo tipo superior. Assim, por exemplo, o negro vai ser capaz de se salvar e pouco a pouco, através da extinção voluntária, as raças mais feias vão pavimentar o caminho para as mais bonitas. As raças inferiores, através da educação, vão se tornar menos prolíficas, e os melhores exemplares vão ascender na escala do aprimoramento étnico. Nessa escala, o tipo supremo não é o branco, mas uma nova raça, a qual o branco também terá que desejar para que se atinja a síntese. O índio, enxertado numa raça com a qual tenha afinidades, vai dar o salto sobre o vazio de um milhão de anos que separa Atlantis de nossa época. Em poucas décadas de eugenia estética o negro vai desaparecer, junto com os tipos que o instinto livre da beleza sinaliza como fundamentalmente recessivos, não merecendo portanto sobreviver. Desse modo haverá um processo de seleção por gosto. Será muito mais eficiente do que o brutal critério de seleção darwinista, que pode ser relevante, quando muito, para espécies inferiores, não para o homem. ${ }^{28}$ 


\begin{abstract}
Esse trecho estabelece três claras conexões entre Vasconcelos e Mistral. Primeira, ambos associam o sexo à transmissão da "cultura", seja a cultura do europeu, sejam as das comunidades indígenas e negras da América Latina. Segunda, ambos privilegiam o branco e a cultura ocidental, ainda que Vasconcelos simbolicamente eleve o mestiço. $O$ fato de a quinta raça não ser idêntica à raça branca sublinha as ambivalências do texto de Vasconcelos: um sentido de inferioridade racial diante da "verdadeira" brancura e um vago mas excessivamente importante sentido de pânico racial surgiram a partir de uma relação iminente e íntima, ainda que involuntária, com os Estados Unidos. Essa sensibilidade é transparente na comparação entre negro e índio. Enquanto reconhece a existência dos negros na América Latina, Vasconcelos relata com satisfação que "eles foram transformados quase inteiramente em mulatos". $E$ ainda usa a negritude para demonstrar que a América Latina não só tem uma estratégia melhor do que a americana para lidar com sua população negra (a assimilação), mas também está mais bem posicionada para obter sucesso na miscigenação, porque tem um outro mais palatável (o índio).
\end{abstract}

Os norte- [i.e., os anglo-] americanos são muito firmes em sua decisão de manter sua linhagem pura, mas é claro que isso é possível porque eles têm o negro diante deles o outro pólo, precisamente oposto ao elemento que eles poderiam eleger para formar a mistura. No mundo iberoamericano o problema não é assim tão extremo. Temos muito poucos negros, e a maioria já foi transformada em populações mulatas. O índio é uma boa ponte para a mestiçagem. ${ }^{29}$

Superficialmente, as populações indígenas saem-se melhor nesse esquema do que as negras, mas é importante notar que elas também estão fadadas a desaparecer no processo de mestiçagem. É precisamente nesse contexto que aparece a atitude de Mistral em defesa das populações indígenas. A comparação entre esses dois grupos, ambos pobres e provendo boas pontes para a mestiçagem, constitui o pano de fundo contra o qual se pode considerar tanto os critérios estéticos, primordiais nas primeiras descrições que Mistral faz do "elemento indígena", quanto seu recurso à idéia de "feio/não feio". Embora essas categorias tenham sem dúvida relação com o racismo de senso comum da época, o fato de Mistral assumir todo um discurso racial nos âmbitos público e oficial exemplifica um gênero de discurso mais sofisticado.

Em uma terceira conexão, Vasconcelos propõe substituir "o brutal critério de seleção darwinista" por uma "eugenia estética": "assim que a educação e o bem comum estiverem disseminados, não haverá mais o perigo da mistura 
${ }^{30}$ VASCONCELOS, 1996, p. 23. de tipos em oposição direta. As uniões vão ocorrer apenas de acordo com [...] a lei da afinidade, sendo refinadas pelo sentido da beleza". ${ }^{30}$ Vasconcelos isola apenas educação e parâmetros do "bem comum" como os principais meios pelos quais o "gosto" e a "eugenia estética" serão cultivados em massa. O Estado supostamente vai administrar essas práticas, embora o ensaio não o afirme. O texto também não indica as crianças como o telos desse esforço, como cidadãos em miniatura ou aspirantes a cidadão. Infância e educação são precisamente as arenas nas quais Mistral se posiciona de forma astuta e agressiva. Tramando os fios que Vasconcelos deixa soltos, ela insiste em afirmar que a mistura correta funda a intervenção pedagógica, uma vez que a criança nacional é a construção desejada pelo sistema público de educação (para enfatizar a noção foucaultiana de educação primária).

A expressão eugenia estética tenta tornar filosoficamente palatável uma ação social insossa. A administração da vida social levou à eliminação de certos sujeitos sociais e à erradicação de suas culturas. Essa perda de vida - vida das pessoas, vida das culturas - precisa ser mascarada como continuação de outra vida, isto é, a vida de uma nação tão gloriosa e importante. Mistral era a favor da eugenia? De acordo com a historiadora Asunción Lavrin, Mistral participou de debates sobre programas de eugenia na América Latina. Suas "idéias sobre eugenia social reproduziam aquelas de higienistas e cientistas feministas de sua geração, e sem dúvida tiveram por base sua experiência no Chile". Lavrin escreve que Mistral defendeu a caridade social organizada para o combate a sífilis, tuberculose e alcoolismo, acreditando piamente que "a qualidade da nova geração" estava em jogo. Em um panfleto governamental sem título, de 1926, ela falou de um "patriotismo biológico" como conceito mais adequado ao Estado do que nacionalidade ou raça, defendendo um papel especial para mulheres como trabalhadoras sociais. "As idéias de Mistral sobre o papel das mulheres nos sistemas de promoção de saúde nacionais iriam em pouco tempo se tornar uma realidade política e pedagógica, visto que as nações do Cone Sul haviam lançado escolas de serviço social, confiando a suas graduandas papéis similares aos que ela sugeria." ${ }^{31}$

Mistral claramente reteve o conceito de nacionalidade e aderiu à idéia da América Latina como uma "raça", ao contrário do que indicavam suas afirmações de 1926. Mas sua defesa do "patriotismo biológico" acabou traindo nela uma compreensão eugenista das populações, que seriam formadas por elementos de raças superiores e inferiores. Ensaios em que ela copia o modelo mexicano 
${ }^{32}$ Sobre a admiração de Gabriela Mistral pelo projeto racial argentino ver MISTRAL, 1978b; MISTRAL, 1979a; e MISTRAL, 1979b.

${ }^{33}$ MISTRAL, 1979c, p. 58-59.

34 STEPAN, 1991, p. 105.

${ }^{35}$ Ver, por exemplo, Patricio MARCHANT, 1996. de mestiçagem obviamente não têm como demonstrar esse fato, mas quando se levam em conta seus ensaios sobre o paradigma argentino da imigração branca é impossível sustentar com alguma convicção que Mistral via as populações indígenas com a mesma consideração com que via os brancos. ${ }^{32}$ Mesmo imigrantes brancos eram às vezes uma questão difícil para ela; em "El floklore argentino", ela fala de folclore como "a defesa da raça contra a imigração perigosa", aparentemente tomando emprestada uma página da política americana: "'a Argentina para os argentinos', plagiando Monroe; conquistando os imigrantes e os nativos [...] através do folclore". 33

Em seu importante estudo sobre os projetos de eugenia da América Latina do início do século XX, Nancy Ley Stepan sintetiza o relacionamento entre raça e pertencimento nacional da seguinte forma:

O desejo de "imaginar" a nação em termos biológicos, de "purificar" a reprodução das populações de acordo com normas de hereditariedade, de regular o fluxo de pessoas através de fronteiras nacionais, de definir em novos termos quem poderia e quem não poderia pertencer à nação todos esses aspectos da eugenia levantaram questões de gênero e raça e produziram propostas ou prescrições invasivas na articulação de novas políticas estatais concernentes aos indivíduos. Através da eugenia, em resumo, gênero e raça foram amarrados à identidade nacional. ${ }^{34}$

Mistral deixou-se atrair pelo problema da definição da população nacional, da determinação de quem seria parte dela, e também pela argumentação sexual que autorizava esse discurso. Suas opiniões constituíam uma forma sutil e insidiosa de eugenia; longe de estarem confinadas a um círculo reduzido de especialistas com influência sobre a medicina e a saúde, essas opiniões foram naturalizadas América Latina afora como "coisas a fazer". Acessível a instituições de massa como as escolas e a imprensa, sua "fala da raça" se tornou sinônimo de uma compreensão nacional de si mesmo, e essencial para o registro afetivo do pertencimento nacional.

\section{Negritude e queerness}

Os críticos entendem que quando Mistral menciona "a raça" ela se refere a uma civilização, não a características biológicas ou a distintas populações da mestiçagem. ${ }^{35}$ Suas referências a uma raça mestiça latino-americana, propõem eles, representam um reconhecimento de 400 anos de mestiçagem cuja suposta linha de chegada mais ou menos coincide com o advento do Estado moderno latino- 
${ }^{36}$ MISTRAL, 1924, p. 173.

\footnotetext{
${ }^{37}$ MARCHANT, 1996, p. 67.
}

\footnotetext{
* "Intermingling" no original [N. do
} T.]. americano, ratificado por um contrato social liberal que dispensa revisões. No entanto, fica claro que as preocupações raciais de Mistral não se referiam diretamente - mas apenas tangencialmente - à sobrevivência de uma civilização vivendo sob a pressão de outras, especialmente seu temido vizinho do norte. Suas preocupações gravitavam em torno de três questões-chave: 1) saber se negros e imigrantes eram parte da mestiçagem latino-americana; 2) o que fazer se eles fossem; e 3) como privilegiar populações indígenas sobre as negras em uma construção binária que, enquanto glorificava a heterogeneidade latinoamericana, controlava seu impacto com firmeza.

Mistral entendeu a conexão, e o contraste, entre construções raciais indígenas e negras no contexto do projeto de Estado. A condição atribuída à mulher indígena gira em torno disso. Em um ensaio pedagógico anterior, "A la mujer mexicana" (1922), ela escreve: "disseram a você que sua pureza é uma virtude religiosa. É também uma virtude cívica: seu útero sustenta a raça; as massas cidadãs nascem serenamente de seu seio, acompanhando o fluir eterno das primaveras de sua terra natal". ${ }^{36} \mathrm{Em}$ outras palavras, a mulher indígena é o receptáculo vedado no qual a raça se mantém pura, o vaso em que a reprodução é aceitável. Essas projeções relativas a fazer a mulher indígena se sentir pura ressoam instantaneamente no projeto eugenista de aprimorar a qualidade da população. A ligação entre o corpo da mulher indígena e o da mulher negra torna-se crucial. Enquanto a mulher indígena é um receptáculo da raça, uma espécie de mãe nacional, a mulher negra é o veículo pelo qual a semente nacional e, portanto, a vida nacional se perdem.

Mistral também se viu como receptáculo da raça. Patricio Marchant resumiu o apelo de Mistral como mãe:

Mistral aparece na mitologia chilena, tanto a popular quanto a literária, [...] como a mãe por excelência [...], competindo com a Virgem Maria por essa posição. Mãe por excelência porque ela é mãe sem filhos. Uma possibilidade que ativa o desejo se o lugar do "filho legítimo" existe como um vácuo [...], se o desejo infantil tem relação com o de ser o filho real, o único, o mais amado. Em termos psicanalíticos, o inconsciente sabe que isso é impossível precisamente a razão que torna a mãe leal, pura, virgem, boa. $^{37}$

Mistral colocou a mulher indígena em uma posição semelhante: inacessivel e remota, afastada de seus filhos logo ao dá-los à luz. A mulher negra é o avesso. Muito acessível e natural, vulnerável demais para trair a raça pela "miscigenação", " ela se torna o próprio agente da poluição biológica nacional. 
38 SANDOVAL SÁNCHEZ, 1996, p. 139-151.

\footnotetext{
${ }^{39}$ MISTRAL, 1978c, p. 118.
}

No ensaio "Primer recuerdo de Isadora Duncan" (1927), amplamente antologizado, Mistral compara o corpo branco de Duncan com o corpo negro de Josephine Baker. Ela privilegia o primeiro como depositário da beleza estética e associa o segundo ao declínio da arte. Esse texto documenta o racismo de Mistral contra descendentes de africanos, chegando a sugerir uma atitude simpática à supremacia branca americana. O ensaio começa com uma referência indireta ao linchamento e, conscientemente ou não, explora a narrativa do linchamento imprimindo um tom sutil mas sensacionalista. A narrativa estrutura-se sobre uma construção racista da violação sexual do corpo de uma mulher branca ou, mais especificamente, do corpo da esposa do homem branco, aquela que carrega seus filhos. Dessa vez, porém, o corpo de uma mulher negra, Baker, é o agente da transgressão. A narrativa de Mistral é homoerótica e racista. Duncan é o objeto do desejo de Mistral (como agudamente percebeu o crítico Alberto Sandoval Sánchez), mas foi indiretamente violentada por outra mulher - uma mulher negra, Baker. ${ }^{38} \mathrm{~A}$ dança "grega" é, numa linguagem figurativa, transgredida pelo Charleston, que na opinião de Mistral é uma dança sexual e degradante, executada por pessoas animalescas e degradantes.

Isadora era também uma yankee, mas uma yankee irlandesa, e de qualquer forma pertencia a uma geração que não havia caído no porão malcheiroso dos traficantes de escravos.

Que vingança curiosa os negros impuseram aos ingleses da América do Norte. Eles que comem, rezam e existem isolados; eles que não podem ter nos braços o corpo de uma mulher branca sem que os filhos de Lynch desçam sobre eles entornando pelo chão sua única parte branca, ou seja, seus cérebros; foram eles que levaram ao inimigo (o Super Homem Branco, como alguns o chamam) seus rebolados obscenos. Eles criaram para os brancos os ritmos bestiais para os quais Nova York agora desperta, com os quais ela vive, com os quais ela dorme.

Isadora deixou esse enorme salão de Charleston em que o mundo se transformou - não tarde demais, graças a Deus, e com a elegância de uma visitante delicada, que abre a porta e se retira discretamente ao ver que seus anfitrióes estão bêbados. ${ }^{39}$

Essa passagem cinicamente vale-se da relação que a narrativa do linchamento estabelece entre raça e sexualidade ou, mais concretamente, entre negritude, sexualidade e crime. Simultaneamente, ela entra em ressonância com o suposto horror das relações sexuais entre membros de raças opostas (um horror já visto em La raza cósmica de Vasconcelos). Mistral, na verdade, distingue 
${ }^{40}$ MISTRAL, 1979c, p. 62-63.

${ }^{41}$ SANDOVAL SÁNCHEZ, 1996, $p$. 145.

\footnotetext{
${ }^{42}$ SAAVEDRA, 1991, p. 84.
}

uniões corretas e incorretas em "El tipo del indio americano", escrito pouco depois de "Primer recuerdo de Isadora Duncan"; aqui ela fala com cuidado da constituição do mulato (mistura de branco e preto). O tema das uniões indesejadas ecoa depois nos comentários de Mistral sobre as conseqüências do casamento de mexicanos com negras. O pânico domina seus escritos sobre essas uniões, e ela revela ansiedade para se mostrar distante de qualquer herança de negritude. Um modo de denegar a existência de negros na América Latina foi deslocar a negritude para os Estados Unidos. Em outro texto em que menciona dança, a comparação aparece de novo: "gosto do tango! Eu disse para Lombardi. Alguns tangos triunfaram por 20 anos sobre o blues americano. Esses ritmos negros não nos vão trazer nenhum bem; eles não são nossos". ${ }^{40}$

Boa parte do artigo de Mistral sobre Duncan descreve um objeto difamado, ou seja, o corpo de Baker, que carrega em si sua própria degeneração. $O$ critério estético autoriza essa descrição violenta, tendo seu refrão na idéia de feiúra, implícita em termos bem marcados como "macaco", "bestialidade", "fedorentos" (que aparecem em todo o artigo) e no "rebolado obsceno" acima citado. Embora Sandoval Sánchez, o único crítico que examinou o texto tenha observado corretamente o "olhar racista" de Mistral para o corpo da mulher negra, ele entende que esse olhar não contém desejo e que essa falta de desejo, esse ódio, vem direto da negritude de Baker, percebida como um substituto de toda a negritude. ${ }^{41}$ Sandoval Sánchez lê na simpática releitura que Mistral faz do corpo insinuante de Duncan a repressão da atração de Mistral por mulheres e, implicitamente, pela brancura. Mas seu desejo queer também aparece no tratamento que dispensa ao sujeito negro e que curiosamente não é reprimido.

Mistral reexamina e retrabalha o racismo injurioso de "Primer recuerdo de Isadora Duncan" quando visita países de fala espanhola do Caribe, e mais tarde o Brasil. Depois dessas viagens, feitas no início dos anos 30, o afrodescendente torna-se um objeto a ser conhecido e incorporado ao discurso estruturado pelo "nós" do americanismo. Em uma carta de 1933 ao escritor e intelectual mexicano Alfonso Reyes, Mistral escreve: "sofri com o inverno americano e com os hispânicos; ambos são brutais. Precisava conhecer uma região de nossa raça da qual eu nada sabia; a língua espanhola da América, suavizada por suas terras e virtudes; e o mulato e o negro, que são diferentes, tão diferentes de nosso mestiço ou de nosso índio. (Como sinto falta do índio Alfonso!)" 42 A presença do sujeito latino-americano negro complica a oposição binária da mestiçagem e a ideologia mexicana segundo a 
${ }^{43} \mathrm{O}$ mais famoso proponente da teoria da "harmonia racial" é o influente Gilberto Freyre. Ver Michael George HANCHARD, 1994

${ }^{44}$ MISTRAL, 1988, p. 77. qual "somos todos mestiços". Mistral substitui sua rejeição inicial da negritude e seu desconforto com a condição de mulato por uma "vontade de saber" e uma "vontade de poder" nietzscheanas. Assim que a negritude aparece como uma presença fundamental e inegável na América Latina, Mistral procura formas de conciliar negritude com mestiçagem, ainda tentando assegurar que a oposição índio/branco continue a ser o motor da história contemporânea da América Latina e a razão de ser de todas as políticas raciais do Estado.

As ideologias latino-americanas de democracia racial tinham por base uma concepção da escravatura latino-americana que a considerava benigna por ser supostamente mais afetiva e erótica. ${ }^{43}$ As queers não escapam desse legado. O desejo queer não é imune às construções racializadas do erotismo ou à tentação de obter a condição de pertencimento à nação através do exercício coletivo da fetichização racial. Em termos globais, o desejo queer tem sido normalmente associado à aceitação privada e à vergonha pública. Dentro da ordem liberal, a condescendência ou o ódio racial aparece normalmente sem censura em ambientes privados, sendo amenizado ou silenciado no discurso público. Assim, uma prerrogativa de cidadania silenciada pelo liberalismo é o acesso a uma esfera privada na qual desejos queer proibidos interagem com o erotismo racializado e hierárquico. Mistral exotiza e sexualiza o sujeito negro nessa esfera privada. Suas cartas à antropóloga e etnógrafa cubana Lydia Cabrera é um exemplo. Antes de viajar ao Brasil, Mistral compartilhou suas intenções com Cabrera:

olha, de verdade, quando quiser ir para lá, por favor não hesite e venha a nossa casa. Sou cônsul em Niterói, uma praia no Rio, separada da cidade por uma linda baía. Apenas meia hora de viagem. É uma sinecura, dificilmente eu terei algo para fazer. Meu estado é o mais bonito e tem a maioria dos habitantes. Lá as pessoas parecem cordiais e elegantes. E, é claro, há também o magnífico negro. ${ }^{44}$

$\mathrm{Na}$ época dessa carta, Mistral estava morando na Itália com sua secretária e companheira, a porto-riquenha Consuelo Saleva, ou "Connie", e atuava como cônsul do Chile. Não se sabe se as cartas reunidas por Rosario Hiriart em Cartas a Lydia Cabrera: Correspondencia inédita de Gabriela Mistral y Teresa de la Parra representam a totalidade da correspondência entre Cabrera e Mistral. Visto que Mistral manteve uma correspondência volumosa com centenas de pessoas, ao longo de toda sua vida, é provável que haja outras cartas.

Molloy demonstrou que a troca de cartas entre Mistral, Cabrera e a romancista mexicana Teresa de la Parra 
${ }^{45}$ MOLLOY, 1995. Mistral pode não ter simplesmente inventado essa comunidade. Cabrera e Parra podem de fato ter compartilhado esse conjunto de imagens de negros fetichizados e subservientes, que pode ter tido algo a ver com a criação das obras de Cabrera, especialmente Cuentos negros de Cuba.

${ }^{46}$ Os mais importantes são El Monte, Yemayá y Ochún e La sociedad secreta abacuá. é codificada como lésbica. Molloy refere-se à participação de Mistral em algumas de suas "brigas de casal" e a seu esforço no sentido de que elas "juntassem os cacos". As assustadoras referências raciais de Mistral e sua falta de autocensura convidam a uma reflexão maior $e$, porque dirigidas a uma destinatária lésbica, podem significar um ponto de vista comum relativo a "pessoas negras". Mistral entende que o negro e a negra, ou a "negritude" em geral, são objetos de desejo de Cabrera e Parra. ${ }^{45} \mathrm{~A}$ companheira lésbica, que compartilha o elo secreto e o medo da vergonha diante da sociedade, participa de um discurso proibido em outras regiões. Talvez o medo da própria Mistral de punição, e portanto de silenciamento, em termos sexuais a tenha levado a declarações desinibidas em termos raciais. É curioso que Cabrera, autora conhecida de livros seminais sobre religiões e "folclore" afro-cubanos, ${ }^{46}$ seja depositária das fantasias raciais e racistas de Mistral, uma vez que Cabrera explicitamente procura retratar os negros de Cuba em termos "respeitáveis", como pessoas profundamente religiosas.

Uma sexualização negativa do sujeito negro é clara em "Primer recuerdo de Isadora Duncan", mas inicialmente Mistral entendeu a sexualização da negritude latinoamericana de forma diferente. Em sua correspondência, ela recorrentemente alude à coleção Cuentos negros de Cuba (publicada em 1936 na França e em 1940 na Espanha), de Cabrera, escrita para entreter Parra, companheira de Cabrera, quando ela estava na Suíça sob tratamento para a tuberculose que acabou sendo fatal. Certamente Mistral sentiu afeição por ambas, Cabrera e Parra, mas havia ainda mais em jogo do que essa amizade: ela pode ter tido vontade de experimentar vicariamente dois circuitos de desejo. Um era o elo entre duas amantes; o outro, relativo à própria Mistral, relativo à incorporação dos contos folclóricos "afro-cubanos" de Cabrera à grande narrativa da América.

Ao contrário de Mistral, Cabrera e Parra eram latinoamericanas abastadas. Com residência no exterior, escrevendo em Paris, onde se conheceram em um barco, longe das praias cubanas, ambas usavam saias e vestidos de estilo impecável, cortavam seus cabelos curtos, no estilo flapper dos anos 20, esbanjavam uma atitude marcadamente "feminina" e liberada. Sua relação com a causa nacional é de exílio, mas em um sentido diferente do que poderia ser para Mistral. Por um simples motivo: elas não precisavam trabalhar, enquanto Mistral precisava. Além disso, o envolvimento inicial de Cabrera e Parra com o discurso americanista ocorreu sob a influência européia do primitivismo, em um mundo de boemia. Nem precisaram se 


\footnotetext{
${ }^{47}$ Rosario HIRIART, 1988, p. 73. Todas as cartas a Cabrera aqui citadas estão na edição de Hiriart; nenhuma tem data, mas todas foram escritas nos anos 30 .
}

articular tanto para ter suas primeiras obras publicadas, enquanto Mistral, depois de labutar por 20 anos como professora de escola no Chile, teve que atrair protetores (homens), e sem lançar mão de coqueteria feminina ou de dinheiro de família.

A ligação entre Cabrera e Parra podia ser ainda mais perturbadora para Mistral por causa da natureza trágica da doença de Parra. A doença é o principal princípio organizador das auto-representações de Mistral. Ela ficou até o fim ressentida por ter tido que trabalhar ininterruptamente desde pequena, mesmo depois de ficar famosa. Irônica e lamentavelmente, ela às vezes sofreu de fato com algumas doenças, incluindo diabete e arterioesclerose, antes de morrer de câncer de pâncreas. Muitos críticos consideraram as referências de Mistral a doença, decadência e envelhecimento como reflexos fiéis de sua própria saúde, mas essa autocaracterização começou muito antes de seu sofrimento. É recomendável, portanto, separar sua própria experiência com doença e decadência de sua assunção de uma subjetividade definida por doença e trabalho excessivo. O tempo livre desfrutado por Parra e Cabrera atraía Mistral profundamente. Definia as amigas como membros de uma classe à qual ela sempre esteve longe de pertencer. $A$ necessidade psicológica de Mistral de se tornar o "sujeito do trabalho" - sujeita ao trabalho, psíquico ou mental, e também subjetivada por ele - tem relação com sua necessidade de se tornar sujeito da doença.

O modelo de escritora nacional de Cabrera e Parra - indivíduos livres das amarras da iconicidade - ressoou profundamente na subjetividade atormentada de Mistral. Tendo- se decidido a representar uma espécie de ética do trabalho latino-americana, Mistral escolheu evidenciar a relação utilitária entre o cidadão e o Estado. Mais do que isso, ela definiu em termos de gênero e de raça a relação de obediência ao bem comum, instaurando-a na psiquê nacional ao posar de mestiça. Cabrera e Parra, ao contrário, permaneceram brancas convictas.

As cartas de Mistral a Cabrera inscrevem o erotismo como fantasia racializada, envolvendo diretamente os negros. A primeira carta começa com uma referência a um discurso racial supostamente compartilhado: "Querida Lydia: não me esqueci de você. Connie está sempre pensando em você também. Acredite, nós duas experimentamos um doce desejo: saber que você está um pouquinho feliz, mas não só com os negros". ${ }^{47}$ O discurso racial funciona como provocação erótica entre casais que guardam certa relação de cumplicidade um com outro. A 
conexão entre "felicidade" e um grupo não especificado referido como "los negros" é feita através desse óbvio tom erótico.

Nessa passagem Mistral explica a substância de seu próprio desejo diante de uma negritude dócil, prontamente disponível:

Eu te amo demais, embora quase nunca o diga. Tive de me mudar algumas vezes; tive de me ocupar com uma quantidade enorme de correspondências, além de dar conta de minha própria doença. E agora o problema de nosso povo, imobilizado na França sem dinheiro. Acho que vou deixar este lugar em breve; não sei quando, ou para onde vou. Tive - poucos meses atrás - um violento desejo de ir para o campo; acho que vou fazer todo o possível para ir para um lugar de pouca gente, onde se fala uma língua estrangeira, e onde eu possa viver na roça lidando com as vacas no pasto e com as galinhas de Angola. Tenho vergonha de perguntar; às vezes me dá vontade de experimentar uma grande aventura e ir embora para morar, sem emprego, num país americano semitropical e trabalhar na roça. Você sabia que [o escritor francês Georges] Bernanos, de tão desesperado, foi para o Brasil e agora mora lá, num lugar bonito e bárbaro, que custou apenas duzentos francos por hectare? Sinto por você. A essa altura você deve ser a perfeita cidadã, senhora de Lyons ou Blois, mas cada vez mais eu sinto que um campo com curandeiros negros, bananeiras e hortas de abacaxi é a solução, tanto para mim quanto para você. Espero poder te oferecer tudo isso em pouco tempo: um lugar sem o frio europeu, sem o homem branco decadente, e cheio de todos esses animais de sua [ilegível].

Assim que conseguir isso eu te conto. Connie começou a arrumar meus papéis do consulado, de forma que eu possa dormir e oferecer minha felicidade aos negros, às negras, e aos campos. Não pense que fiquei louca por causa da guerra; venho pensando muito nisso. ${ }^{48}$

Pessoas negras ocupam um espaço paralelo àquele das mulheres e das populações indígenas, já que as três categorias são articuladas no discurso latino-americanista como representações de tempos arcaicos, anteriores à modernidade. Mas além disso, para Mistral, bem como para o discurso americanista que ela ajudou a consolidar e que eventualmente representou, pessoas negras ocupavam um espaço muito diferente daquele relativo às populações indígenas. Com certeza, tanto negros quanto indígenas são partes do espetáculo. Povos indígenas pertencem ao teatro do trabalho; são circunspectos e afastados da vida social, ainda que contribuam materialmente com ela e ancorem o sujeito nacional em um tempo originário. Negros, porém, existem para Mistral em uma relação sem especificidade, 
${ }^{49}$ HIRIART, 1988, p. 74 e 77.

mas claramente lúdica - não precisamente infantilizada. A interação entre eles e ela se dá num tempo de sonho, e só pode ter lugar num cenário pastoril, nos "campos".

Curiosamente, mulheres e povos indígenas são sempre sujeitos do trabalho, sempre úteis e produtivos, seja em relação ao trabalho, seja em relação às crianças. Mistral afirma sonhar com o Brasil, onde poderia trabalhar menos e "conseguir mais com seu dinheiro", por assim dizer. O que precisamente ela vai conseguir mais? Mais terra, mais tempo para escrever, e mais prazer - correndo pelos campos -, um desejo explicitado pela referência às pessoas negras como fetiches. Naquela passagem, Mistral "se casa" com o tempo livre. Essa metáfora contrasta nitidamente com seu "casamento" real com Connie, que se entrega ao trabalho de manter em ordem os assuntos de Mistral, assim como fazem todas as suas "secretárias". O casal lésbico surge como o epítome da ordem social, da utilidade, divorciado do desejo. Cabrera e Parra, em parte por trafegar nesse discurso racial divertido (privado e sexualizado), representam um casal bem diferente.

O desejo de Mistral, transcendendo suas próprias fantasias, é projetado em uma tela nacional de fantasias. Ela exibe um claro interesse na publicação dos contos folclóricos de Cabrera. Oferecendo-se para ter Cuentos negros de Cuba publicado no Chile e para prefaciá-lo, Mistral repreende Cabrera por não trabalhar tão duro no livro. Mistral argumenta que, uma vez que os contos foram publicados originalmente em francês (Contes nègres de Cuba), seria imperativo que fossem publicados na Espanha, podendo assim encontrar seu verdadeiro público. Limitar o livro ao francês é literalmente um crime [uma villania].

Por que você não escreveu? Quando você vai terminar o que começou? Você quer seus Cuentos negros publicados no Chile? Faça várias cópias datilografadas, e, já que você tem meu endereço, mande-os para mim. Está me ouvindo? O hispânico é um caso de suicídio nato, mas eu espero que você ainda tenha três gotas de sangue índio e que elas te salvem $[\ldots]$

Quero que você publique a tradução espanhola dos Cuentos de uma vez por todas. É um crime manter o livro só em francês. Está me ouvindo? Sinto-me repetitiva te oferecendo um prefácio. É seu. ${ }^{49}$

Apesar da oferta, Mistral nunca escreveu o prefácio, e o livro nunca foi publicado no Chile. Em vez disso, o famoso cunhado de Cabrera, o antropólogo Fernando Ortiz, redigiu o prefácio, e o livro foi publicado em Cuba em 1940.

O que Mistral teria escrito em seu prefácio para os Cuentos? Certamente ela não teria incluído sua fantasia racial sobre pessoas negras correndo pelos campos ou 
${ }^{50}$ Citado em E. Fernández ARREDONDO, 1930, p. 1. sobre curandeiros. Mas um tom impróprio teria vazado para o prefácio, como aconteceu com outros de seus escritos sobre o Caribe e o Brasil. Seu ensaio "Antillas" foi mal recebido pela intellligentsia cubana, que se ofendeu com sua descrição das ilhas do Caribe como "um cigano não muito chegado a um banho". ${ }^{50}$ As representações que Mistral fez de crianças negras de escola em seus escritos pedagógicos são comumente ofensivas. Em "Recado sobre las voces infantiles", por exemplo, ela as descreve como seres que estão constantemente dançando, rindo e cantando. Balançando seus ombros e quadris "para qualquer coisa", elas são pequenos corpos prazerosos que às vezes caem em uma introspecção impenetrável, quando se tornam melancólicos e calados. Em lugar algum na correspondência e na prosa conhecida e publicada de Mistral aparece derrisão ou condescendência desse nível em relação a populações indígenas. ${ }^{51}$ Elas são vistas como infantilizadas em outro sentido: no imaginário racista, elas exigem intervenção paterna para serem modernizadas. $O$ Estado precisa supervisionar o trabalho delas. Pessoas negras, ao contrário, são sexualizadas, como acontece com Josephine Baker ou com os "curandeiros", ou criminalizadas, uma caracterização que se tornou pessoal depois da morte do filho adotivo de Mistral.

\section{Mulataje e queerness}

Os textos de Mistral sobre sua estada no Brasil, onde o governo chileno a alocou, a pedido dela, assim que estourou a Segunda Guerra, são marcadamente negativos. Mistral não experimentou sua fantasia racial enquanto foi cônsul em Petrópolis, e seu filho adotivo, Juan Miguel Godoy, suicidou-se em 1943. Esses dois eventos - a dissolução de sua fantasia e o trauma da perda real - levaram Mistral a compor estridentes acusações de xenofobia contra uma vaga categoria de mulatos brasileiros delinqüentes, negando a inclusão do Brasil na categoria da mestiçagem:

[para Tomic, 1948] lá se vão cinco anos desde o assassinato de Yin Yin (ele não cometeu suicídio; foi "suicidado" por mulatos xenófobos). Sua sombra caminha a meu lado. Mas não é terrível, e sim doce e fiel.

[para Reyes, 1948]. Naquele país horroroso de que você gosta tanto - o Brasil - três médicos me arruinaram quando me trataram de diabetes e de amebíase tropical. São uns estúpidos, assim como a maioria da população.

[para Tomic, 1951]. Você pode achar estranho, mas deixa eu te contar, eu não tenho intenção de sair da ltália. Acabei amando esse país bem mais do que amaria uma pessoa. Eu me odeio por tê-la deixado e ido embora aturar a xenofobia dos mulatos brasileiros. Eu sacrifiquei Juan Miguel 
52 SAAVEDRA, 1995, p. 150 e 131; SAAVEDRA, 1991, p. 220 e 160.
53 “'SOBRINO'..., 1999; "POLÉMICA..., 1999. Teitelboim menciona especulações anteriores a respeito do assunto (TEITELBOIM, 1991, p. 213). por aquele país. Você o tem em alta estima porque $\circ$ conhece muito pouco. Lá eu conheci a xenofobia mais odiosa e tribal.

[Para Reyes, 1954] É tão triste não ter família, meus amigos! Não tenho nem um primo em quarto grau. Anos atrás escrevi alguns versos mais ou menos assim: 'Os meus vão comigo noite adentro'. E estava certa. Se tivesse alguém, eles o matariam, bem ao estilo brasileiro, e então diriam que ele se matou, como Yin supostamente fez. (Como eu demorei para entender isso! Como eu sofro por ele!) A 'gangue' chegou a minha própria mesa numa noite de Natal. Cinicamente confessaram seu feito. Depois de eu ter ofendido a memória dele com esse ódio contido! Nunca se sabe todos os fatos sobre algo. Às vezes nem um pingo. ${ }^{52}$

A palavra mulataje apareceu pela primeira vez no artigo "El tipo del indio americano", em 1932, pouco antes da correspondência com Cabrera. Para entender plenamente as implicações da defesa sempre muito evidente que Mistral faz da mestiçagem, é essencial entender as implicações conceituais da mulataje. A palavra não é meramente capaz de descrever uma mistura racial particular - branco com negro - mas também denota a presença de uma ameaça racial: a destruição das crianças brancas e da família branca. Mulheres indígenas podem funcionar como receptáculos para carregar a semente do homem branco. Sua marca racial é racionalizada como menor, comparada com a marca degradante e deformadora atribuída a pessoas negras. A sexualização dos negros leva a sua patologização como assassinos.

É central para a narrativa racial do Brasil feita por Mistral a lembrança da morte de seu filho, carinhosamente chamado de "Yin Yin". As circunstâncias do nascimento - e da morte - de Yin Yin não são claras. Mistral afirma que ele era seu sobrinho, filho de um irmão ilegítimo que ela não conheceu e de uma espanhola. Como exatamente ela o localizou, ou foi encontrada pelos pais dele, nunca foi explicado. Alguns críticos suspeitam de que Yin Yin não era de fato parente de Mistral, mas simplesmente um garoto espanhol que ela adotou enquanto morou na Espanha. Recentemente uma TV chilena transmitiu uma entrevista com a última companheira de Mistral, a americana Doris Dana. Dana alegou que antes de morrer Mistral "confessou" a ela o segredo do nascimento de Yin Yin: ela própria seria a mãe biológica de Yin Yin. No entanto, Dana não acrescentou outros detalhes biográficos, nem forneceu qualquer indicação sobre quando o nascimento ocorreu, sobre como e onde Mistral se escondeu nos últimos meses de gravidez, nem quem era o pai. ${ }^{53}$

Aos 16 anos Yin Yin ingeriu uma dose letal de arsênico, e sua morte foi considerada suicídio. Mistral, que nunca 
${ }^{54}$ SAAVEDRA, 1991, p. 218

conseguiu superar a morte do filho, criou uma narrativa pela qual ela se isenta de responsabilidade pelas ações dele. No trecho a seguir, de uma carta de 1954 para Reyes, por exemplo, Mistral relê o acontecimento como um assassinato racialmente motivado por uma "gangue" de crianças negras:

No Natal, a gangue que o atormentava na escola veio a minha casa. Todos quatro. Eu juntei coragem e perguntei por que eles haviam matado uma alma tão doce, que foi um amigo tão bom para cada um deles. Esta foi a resposta: - Sabemos que a madame ainda está contrariada com isso, mas tinha que ser.

Eu pulei de minha cadeira e perguntei: por que "tinha que ser"?

- Ele tinha mais do que a parte que lhe cabia.

- O que ele tinha a mais do que "a parte que lhe cabia"? Eu tinha que inventar alguma coisa para ele sair comigo. Eu tinha que dizer que iríamos comprar roupas e sapatos para mim.

- Ele tinha o nome dele, o seu nome de escritora, madame, que Ihe dava prestígio. E ele era branco demais para seu próprio bem.

- Bandidos, eu disse. A brancura dele e a negritude de vocês não eram culpa dele. ${ }^{54}$

Mistral acredita que a morte de seu filho resultou de três fatores: ciúmes de suas posses materiais, o privilégio da brancura, o prestígio da mãe escritora. Mistral posiciona-se no centro da narrativa, como razão do assassinato e como a fonte última da brancura. A relação que importa é entre ela e a "gangue". A morte de Yin Yin é secundária. Mistral está convencida de que a morte dele foi causada pelo excesso de negros em volta dele (são quatro crianças negras para uma branca). Sob seu olhar racista, o desequilíbrio de poder favorece criminosos violentos. Curiosamente, a cena do crime é a escola, os criminosos são crianças da escola e a vítima é um aluno.

Esse trecho representa outro lado da fantasia racial do excesso em Mistral. Nesse cenário rompe-se a díade mãe-criança. A mulataje, palavra depreciativa que indica a mistura racial de branco e preto, é responsável pela desaparição da família (branca). Em outras palavras, ela interrompe a mistura harmônica da mestiçagem e destrói a família nacional. O sujeito negro torna-se excessivo outra vez, mas agora é abertamente considerado violento, criminoso e cínico.

As crianças más ("bandidos") alegam a importância de Mistral como escritora como um dos motivos do "assassinato", estabelecendo a ligação entre brancura, escrita, reconhecimento e fama. O narcisismo de Mistral duplica-se como narcisismo nacionalista no contexto de um 
${ }^{55}$ Ver SKIDMORE, 1990; e Aline HELG, 1990.

${ }^{56}$ Citado em TEITELBOIM, 1991, p. 214. país conhecido por instituir políticas profiláticas de imigração, a fim de manter a chamada semente ruim do lado de fora. Na época essas políticas de imigração andavam lado a lado com políticas de embranquecimento, não só no Brasil, mas em todos os países do Cone Sul. ${ }^{55} \mathrm{Em}$ suas aulas de 1976 no Collège de France, Foucault sugeriu que no biopoder a guerra entre as "raças" é substituída pelo racismo de Estado, caracterizado por um impulso homicida e suicida rumo à purificação da própria raça, através do extermínio de elementos da mesma nação. A fábula moralista de Mistral lembra de forma sinistra a observação de Foucault, uma vez que fornece uma justificativa racial para a morte da raça, alegoricamente identificada no "assassinato" de Yin Yin.

Reyes foi o mesmo correspondente para quem Mistral descreveu suas primeiras reações ao sujeito negro latinoamericano; ele é o destinatário privilegiado quando Mistral escreve sobre suas preocupações raciais. A história da morte de seu filho, porém, não circulou apenas entre conhecidos e amigos. Mistral a incluiu em seu relatório consular de 1947 para a República do Chile, onde ela aparece como parte do registro de Estado: "minha trágica experiência no Brasil - a morte de meu parente, provocada pelo fato de 'ele ser branco demais para seu próprio bem' - permanece como uma ferida aberta em minha memória". ${ }^{56}$ Especialistas em Mistral concordam que a acusação de assassinato que ela faz é falsa e que Yin Yin cometeu suicídio. Atribuem a narrativa a lucubrações delirantes de Mistral, provocadas pela mágoa, pela doença e/ou pela idade. No entanto, suas implicações racistas e violentas não devem ser sumariamente desconsideradas.

Poder-se-ia pensar que a acusação de xenofobia feita por Mistral contra o Brasil estivesse restrita ao espaço privado ou extra-oficial, ou seja, a sua correspondência, mas um de seus últimos ensaios, "Imagen y palavra en la educación", apresentado como um discurso em 1956, pouco antes de sua morte, sugere algo diferente:

às vezes o estrangeiro vai até lá por ter lido no jornal que o país precisa de especialistas nesse ou naquele ramo. Ou vai simplesmente para gozar de um clima recomendável para a saúde. De repente aparece um cadáver num apartamento ou na rua. A cidade então fica sabendo que uma criatura inofensiva, que um dia celebrava o belíssimo país que o sustentava, foi eliminada sem qualquer razão. Só por causa de uma antipatia grotesca por um rosto branco de olhos azuis. A investigação começa. Quando o criminoso ou seu cúmplice é encontrado, ele normalmente declara sem o mínimo remorso, e muitas vezes com orgulho de ter eliminado o estrangeiro, que "o homem era branco demais 
para seu próprio bem". Estou contando aqui minha própria experiência, a de meu parente. Eu a ofereço sem mencionar o país, por respeito, já que é um país latinoamericano. [...] Falo em nome daqueles que não podem falar por si mesmos. Falo porque é absolutamente necessário que nessas regiões do mundo nós acrescentemos ao código penal o crime da xenofobia, um crime pouco conhecido mas freqüente. Não vou dar os nomes desses países, porque a única coisa com que me importo, enquanto cristã, é que o crime racial desapareça de uma vez por todas da face da Terra. Falo de crimes cometidos por causa de peles claras ou escuras, ou simplesmente por alguém falar uma outra língua. ${ }^{57}$

Essa passagem mostra a mesma ambivalência que reveste "Primer recuerdo de Isadora Duncan" quanto à supremacia branca legalizada. Mistral coloca-se contra crimes raciais mas se recusa a escolher como exemplo representativo as vítimas óbvias do crime racial na América Latina: povos negros ou indígenas. Em vez disso, o exemplo de xenofobia que ela fornece é um crime inventado cometido contra Yin Yin (agora "um homem").

A parte culpada passa a ser um país inteiro, destacado como negro, latino-americano, de fala nãoespanhola e criminoso. O Brasil é retratado como um país criminoso e perigoso. Mistral codifica a identidade negra do país, em linguagem oficial, como xenófoba - e o ódio ao estrangeiro torna-se ódio à brancura. A Mistral que era mestiça agora é branca - "branca demais para seu próprio bem". E a Mistral escritora da nação latino-americana está em perigo. Ela sintetiza a América Latina, e a América Latina - pelo menos aquela que tem que sobreviver - é branca.

\section{Imigração e queerness}

A mulher indígena é aquela que carrega os filhos mestiços da nação. A mulher negra cria os filhos negros assassinos. Ambas são subordinadas, é claro, às elites brancas. As elites sempre buscam, como primeira solução, manter intacta sua brancura, seja preservando-se como pequeno e poderoso grupo proprietário de terras, isolando suas mulheres de qualquer perigo de contágio, seja promovendo agressivamente políticas que visam a embranquecer e europeizar a população em geral. Assim, não há como separar a sexualidade queer na América Latina da prevalência branca na hierarquia social nacional.

Algumas notáveis queers latino-americanas, como Mistral, dedicaram-se, de forma igualmente notável, a manter seu status de "pessoas brancas". Escritores e intelectuais queer dos mais importantes voltaram seus olhares para a imigração como solução para a 
${ }^{58}$ Sobre a ambivalente recepção de Mistral no Chile ver SANTELICES, 1972; e TEITELBOIM, 1991.

${ }^{59}$ Elizabeth Rosa Horan registra uma das raras alusões diretas à masculinidade de Mistral já publicadas. É o texto "La signatura de la esfinge", de Arévalo Martínez, que, "com sua capa de ficção é o único a registrar aquilo que os contemporâneos de Mistral pensavam e falavam sobre $\mathrm{o}$ assunto, mas que não publicaram (HORAN, 1994, p. 222).

${ }^{60}$ MISTRAL, 1994. problemática racial nacional. As manipulações discursivas da mestiçagem, da mulataje e da própria imigração aconteceram ao mesmo tempo, adequando-se às subjetividades e dando forma à escrita de boa parte do cânone queer latino-americano.

Mistral não pôde buscar plenamente uma carreira literária no Chile, e foi indiretamente expulsa do país, mesmo sendo considerada uma emissária, um símbolo nacional. Como já indicaram alguns especialistas em Mistral, a atitude do Chile diante de seu próprio ícone sempre foi conflituosa. ${ }^{58}$ A ambivalência tinha relação com a condição ambígua de Mistral em relação ao gênero: o patriota internacional mais famoso do Chile não era um "filho", mas uma "filha", e isso sem dúvida foi experimentado como um dilema psíquico, sugerindo uma origem queer para a nação. A filha amada do Chile era também a "mãe" da mesma nação, mas essa mãe mais parecia um homem. Mistral era masculina, tanto na aparência quanto nos gestos, e habitava uma esfera pública comandada por homens. ${ }^{59}$

A questão sobre quem pode entrar no Chile e quem não pode domina os textos de Mistral sobre imigração. No artigo "Sobre la mujer chilena" (1946), Mistral lista as "melhores" migrações do Chile, bem como as "improdutivas". 60 Sua insistência na diferença racial e na oposição entre misturas raciais corretas e incorretas é impressionante; lembra sua argumentação sobre raça exposta em "El tipo del indio americano" e depois ecoa em sua vida como uma espécie de paranóia, tendendo às vezes a um nacionalismo fascista.

A questão da reprodução também é central nas articulações de Mistral em torno da imigração. Curiosamente, a imagem que ela faz da mulher indígena isto é, uma mulher que superou a condição de abominável para tornar-se linda - estranhamente refletiu a experiência da própria Mistral no Chile. De objetos de desdém e até ódio, ambas as imagens evoluíram para a beleza e para o receptáculo privilegiado da nacionalidade, que no entanto permaneceram do lado de fora, de forma significativa. Mistral tornou-se um ícone reverenciado no Chile (em grande parte fabricado), a partir do momento em que deixou de viver lá. Sua elevação foi resultado de seu deslocamento para além dos confins nacionais. A mulher indígena pode ter sido o receptáculo da raça, mas ela nunca foi louvada como um ator social importante, muito menos como um líder.

É lugar-comum dizer que Mistral foi a primeira chilena a defender o mestiço e batalhar por melhorias nas vidas dos povos indígenas. Esse aspecto da mestiçagem, supõese, não pode faltar no discurso tradicional chileno sobre raça e nacionalidade. No entanto, toda a idéia de uma 
${ }^{61}$ Referências importantes para o caso do Chile incluem Néstor PALACIOS, 1986; Vicente Pérez ROSALES, 1970; e Francisco Antonio ENCINA, 1978.

\footnotetext{
${ }^{62}$ Agradeço a Marcial Godoy indicar-me o texto de Palacios. Sonia Montecinos resgatou a formulação em seu interesssante livro Madres y huachos: alegorías del mestizaje chileno (MONTECINOS, 1991)
}

${ }^{63}$ MISTRAL, 1994, p. 61. personalidade chilena, uma chilena autêntica, é um projeto racial em si mesmo (retomando a útil formulação de Omi e Winant). Além disso, não se trata do primeiro exemplo de reivindicação em favor dos índios no contexto da construção nacional. Pensadores chilenos importantes já recorreram a um argumento biológico baseado na mistura racial para desenvolver a idéia de uma personalidade chilena e de um destino coletivo. ${ }^{61}$ Néstor Palacios, autor de Raza chilena, glorifica o roto chileno como a gênese do chileno moderno, o descendente dos igualmente belicosos aruaques e teutônicos. Sua referência a uma "raça mestiça" representa uma profissão de fé fascista à depuração racial, definida pela guerra civil social e biológica. Trata-se também de uma mestiçagem completamente afetada pelo gênero: mulheres indígenas têm relação de paridade com homens brancos. Palacios atribui o sucesso dessa mestiçagem à "boa sorte" dos teutônicos, que mantiveram sua raça "pura" até o momento em que conquistaram o Chile. Conforme esperado, ele privilegia a raça branca nessa construção. ${ }^{62}$ "Sobre la mujer chilena" dá um exemplo das racializações diferenciadas de mulheres e de sua posição estratificada na função de reprodução pelo bem da nação:

Basta olhar e ouvir por um breve momento para saber que - refúgio nas altas tocas dos condores é obra de uma única mulher. $\mathrm{O}$ homem andino nada sabe além de descer às minas [...] e dinamitar pedras. Ele não liga para si mesmo; ele não consegue formar um ninho. [...] Se ele não tem essa mulher a seu lado, ele escorrega, dia após dia, para o barbarismo dos primeiros índios. O tipo de ação pura, de ação sem preço que é a marca do homem chileno, de Lautaro a Portales, parece tomar conta de sua companheira, afastando-a das vicissitudes do sedentarismo e transformando-a em seu semelhante. ${ }^{63}$

A mulher é branqueada como o oposto do homem indianizado, dominado pela tendência ao barbarismo. A mulher é também masculinizada, assumindo a prerrogativa masculina, porque o homem se tornou perigosamente efeminado, tanto quanto bárbaro. Considere a narrativa de Palacios sobre a Conquista: o teutônico forte chegou no último minuto para fornecer sua semente à mulher indígena e criar a forte raça chilena. Mas aqui a mulher é branca, e o homem é índio. Ao contrário da mulher indígena, intemporal, imóvel, essa "mulher mestiça ou branca" está a caminho de compensar a falta de comportamento masculino de seu "homem".

Dizem que ela é "temperamental". O ponto inicial de seu êxtase é quase sempre o amor, de cuja chama emerge a mais sensata das ações, bem como a mais desenfreada 
${ }^{64}$ PALACIOS, 1986, p. 62 das fantasias. Essa mulher branca ou mestiça segue seu homem rumo ao deserto de sal, sem repreendê-lo por seu exílio. Essa mulher corajosa vai criar seis filhos no Central Valley, espichando um salário capaz de sustentar apenas dois. Ela vai migrar para não perder sua natureza errante. Ela vai chegar às províncias argentinas ou à Califórnia, onde vai batalhar seu pão em meio a todos os estrangeiros. Se ela é jovem e se arrisca a ir à escola, ali ela vai também se sair vitoriosa em tarefas criativas e na arte sutil de construir um lar. ${ }^{64}$

Mais do que uma noção sentimentalizada de maternidade ou um disfarce para a ausência de filhos da própria Mistral, a reprodução é de fato uma questão de hierarquias, especificamente hierarquias raciais. A imigração não é um caso de generosidade nacional, tolerância ou senso prático; é uma batalha a que o mais forte sobrevive. Aparece aqui, no entanto, o apelo a uma linguagem psicologizada, afetada pelo gênero. O dualismo entre ações sensatas e fantasias desenfreadas é altamente sugestivo no contexto da lealdade nacional. Mistral fala de "amor absoluto", estabelecendo a mulher branca como exemplo ativo para a ralé, um tipo de veículo diferente daquele da mulher indígena. Esse argumento sugere que o Estado precisa fazer mais do que apelar à razão ou ao utilitarismo; precisa também incorporar ou acender outras emoções, especialmente aquelas mais diretamente associadas à mulher queer, já que no fim do trecho acima há uma guinada um tanto queer em direção à educação que não se encaixa bem na descrição.

Assim, Mistral torna queer o pensamento racial nacional. Entretanto, suas alianças silenciosas com os chilenos racialmente privilegiados têm uma genealogia clara. Essas alianças são poderosas justamente por serem internalizadas, silenciosas e inquestionadas. O discurso racial latino-americano tende a resolver misturas raciais conflituosas através de binarismos: mestiço indica branco/ índio; mulato indica branco/negro. A questão da imigração provê o Estado com o assombroso espectro das combinações intermináveis, mesmo quando ele utiliza a imigração para branquear a população. Esse é o contexto no qual o alinhamento de Mistral ao modelo mexicano de mestiçagem deve ser entendido.

Mistral considera a verdadeira heterogeneidade racial algo perturbador, e só mesmo o binarismo implícito na mestiçagem era confortável para ela. Para Mistral, a mestiçagem era uma construção plenamente afetada pelo gênero, mais ou menos como o argumento de Palacios. Mistral discutiu suas idéias com seus contemporâneos. Em uma entrevista de 1948 a Salvador Novo ela esperava poder 
${ }^{65}$ NOVO, 1948, p. 4.

${ }^{60}$ SCHNEIDER, 1991, p. 10. fazer seu desconforto sobre o assunto chegar diretamente a Miguel Alemán, presidente do México. ${ }^{65}$

Alemán recrutou Mistral através de Jaime Torres Bodet, convencendo-a a voltar ao México. Alemán provavelmente esperava que ela fixasse residência em Veracruz, já que ela estava constantemente procurando o lugar perfeito para viver e o clima perfeito em que pudesse cuidar de suas indisposições cada vez mais freqüentes. Mais precisamente, a saúde de Mistral justificava sua preferência por climas "tropicais". Mas suas tentativas de fixar residência em Porto Rico, no Brasil, em Santa Bárbara (na Califórnia) e em Veracruz estranhamente coincidem com agendas estatais relativas a populações negras.

Não se sabe ao certo por que Mistral foi convidada pela segunda vez a morar no México. Por volta de 1948, quando chegou a Veracruz, ela já havia se afastado de Vasconcelos, seu antigo anfitrião. O pesquisador mexicano Luis Mario Schneider observa que "está faltando uma informação precisa sobre o objetivo da segunda visita de Mistral ao México. Talvez a documentação seja encontrada algum dia nos arquivos oficiais. A única coisa que sabemos ao certo é que Jaime Torres Bodet, ministro de relações exteriores, fez o convite oficial em nome do presidente Migule Alemán". ${ }^{66}$ Schneider percebe que deve ter havido um motivo político para o convite, o que não seria de surpreender, uma vez que convites oficiais têm sempre uma inclinação política. No entanto, é altamente significativo o fato de que Mistral tenha sido solicitada a fixar residência em Veracruz, historicamente o estado com a maior população negra no México. Ainda que, como Sagrario Cruz e outros pesquisadores vindos da Antropologia já apontaram, os mexicanos que vivem em Veracruz e descendem de suas comunidades negras raramente se identificam como negros. Esses historiadores e antropólogos consideram essa falta de auto-identificação uma conseqüência do esforço do Estado mexicano de promover agressivamente a mestiçagem como a identidade dos mexicanos por excelência. Sustentam que os negros mexicanos foram eliminados do discurso público para que os povos indígenas possam ser tidos como os verdadeiros subalternos do México. Alguns estudos sobre os negros mexicanos da era colonial apareceram, mas pouca pesquisa foi feita sobre a política adotada pelo governo em relação a eles imediatamente após a Revolução Mexicana. Pode-se argumentar, dada a importância de Mistral no esforço de propaganda de Estados latinoamericanos e à luz de sua correspondência e de suas entrevistas com intelectuais mexicanos, que o convite do 
${ }^{67}$ NOVO, 1998.

${ }^{68}$ NOVO, 1948, p. 4.

${ }^{69}$ SAAVEDRA, 1991, p. 193-194 e 195. governo estava ligado, pelo menos em parte, a uma política disfarçada em relação à negritude.

Um desses intelectuais, Salvador Novo, oferece um ponto de comparação interessante. Hoje ele seria considerado um escritor gay "assumido". Escreveu sobre suas façanhas sexuais em sua autobiografia, La estatua de sal, que ficou inédita e esquecida até o recente resgate feito pelo importante escritor e intelectual mexicano Carlos Monsiváis. ${ }^{67}$ A partir do texto, fica claro que a homossexualidade de Salvador Novo era tudo menos secreta. Assim, torna-se razoável perguntar se a sexualidade de Mistral também não era apenas um fato conhecido, mas também, talvez, um ingrediente da atração que ela exercia sobre o projeto que a coloca como mãe da nação.

Ao discutir a permanência de Mistral em Veracruz, Schneider alude a uma entrevista com ela feita por Salvador Novo para a imprensa mexicana. Schneider destaca poucas linhas da entrevista. O texto completo contém uma alteração significativa:

[Salvador Novo:] E então ouvi de seus lábios uma defesa, que transcrevo aqui e assino embaixo com extremo fervor: [Mistral:] "Há uma coisa para a qual eu deveria chamar a atenção do presidente Alemán. É uma situação grave e perigosa, e muito dolorosa, para esses mexicanos que cruzam a fronteira para trabalhar na Califórnia. É urgente e necessário que se cuide dessa situação imediatamente". [Salvador Novo:] Gabriela Mistral mora em Santa Bárbara, Califórnia, estado da União cujas leis proíbem o casamento de mexicanos - "pessoas de cor" - com mulheres brancas. Quando estes acontecem, são anulados, e os noivos são multados, mas não são muito freqüentes. Os caminhões de gado são carregados de trabalhadores mexicanos. Homens solteiros são levados a morar em bairros separados, onde são discriminados. O único contato que lhes é permitido é com mulheres negras, feias, da pior espécie. Com o passar dos anos, toda a região ferve de criaturas mestiças de sangue negro e mexicano, uma mistura que degrada e anula a boa raça mexicana.

[Mistral:] "Por que em nome de Deus eles não deixam os mexicanos levarem suas mulheres com eles" [...]

[Salvador Novo:] Connie ouviu nossa conversa, e oferecia novos e dolorosos exemplos dessa situação trágica. ${ }^{68}$

Novo não exagerou a animosidade racial de Mistral ao relatar a entrevista. Ela repete cada palavra do relato em correspondência de 1950 com Reyes, referindo-se a essas crianças como uma ameaça à identidade nacional. "Logo ferve uma mulataje, e isso, isso é o que chamam de mexicano!" Reyes responde: "É algo de fato muito sério a condenação da mulataje que você menciona. Vou falar com as pessoas certas". ${ }^{69}$ 
Aqui Mistral acredita que a questão da reprodução nacional está em risco; ela acha que o sexo entre homem mexicano e mulher negra, assim como os filhos que dele resultam, é inaceitável, não é latino-americano. E há outros pontos a se considerar aqui, mais sutis e fascinantes. Primeiro, Mistral dirige-se a Salvador Novo, outro protótipo do escritor nacional e, como Mistral, gay e empregado pelo Estado (no Ministério da Educação, nada menos). Segundo, a anedota encerra-se com uma referência a "Connie", companheira de Mistral. Um triângulo de intelectuais queer discute a possível desaparição da raça mexicana, causada por uma negritude não regulada, especificamente por mulheres negras. Todos se apropriam de mulheres da mesma nação como "suas", servindo a uma função, a reprodução, que tem uma única finalidade: produzir os melhores filhos da nação, os mestiços. Mas nenhum desses três sujeitos queer produziu biologicamente uma criança sequer, muito menos mestiça. Mesmo o filho de Mistral era enfaticamente representado como branco. A conversa deles levanta uma questão: por que os filhos de homens mexicanos e mulheres negras (supostamente americanas) não deveriam também ser considerados mestiços?

Uma coisa é clara: Mistral esforçava-se para se tornar o receptáculo vedado da raça, precisamente como a mulher indígena que ela glorificava. Ela se considerava um veículo de reprodução, guardiã da essência nacional e racial, e de um modo perverso sua queerness a incita a se colocar como alguém feita sob medida para a tarefa. Se em público ela freqüentemente se referia a si mesma como feia, no âmbito privado ela pode muito bem ter se visto como especial, talvez até bonita. Referindo-se a mulheres negras como "feias, da pior espécie", não estaria ela se apresentando como o lugar da beleza, como produto de uma bem-sucedida "eugenia estética" promovida por Vasconcelos? Cooperando com outros intelectuais queer para estabelecer um ideal heteronormativo de respeitabilidade, não estaria ela afetando a forma da futura queerness latino-americana?

A idéia de raças feias, formulada por Vasconcelos, sobreviveu no trabalho de Mistral até o fim. Apesar dos louvores de seus discursos oficiais, Mistral nunca abandonou a crença íntima de que afro-latino-americanos não eram latino-americanos e não tinham os requisitos estéticos "da raça". Enquanto Vasconcelos acreditava na superação voluntária das raças "inferiores" (das quais os negros são o exemplo que ele fornece), Mistral defende que os casais de mexicanos e negras deram ao mundo filhos inaceitáveis, de heranças mestiça e negra, filhos que por definição não poderiam ser latino-americanos, já que não correspondiam 
" A escolha do termo "recusa" para o "disavowal" do origina deve-se a seu uso na psicanálise em português, visto que a autora, mais adiante, Ihe realça esse sentido psicanalítico. Ambos os termos correspondem à Verleugnung freudiana (cf. Jean LAPLANCHE e Jean-Bertrand PONTALIS. Vocabulário da psicanálise. São Paulo: Martins Fontes, 1995. p. 436) (N. do T.).

${ }^{70}$ Agradeço a Janet Jakobsen a formulação desse argumento em meu trabalho. ao critério estético. Note-se que essa visão não era unicamente de Mistral. Era também de Reyes e de Salvador Novo, dois pilares da mestiçagem latino-americana ideal. A escrita queer latino-americana, portanto, é, pelo menos em algumas ocasiões importantes, imbricada com o desejo heteronormativo.

\section{Conclusão}

Três operações críticas têm lugar na obra de Mistral sobre o sujeito da "raça" latino-americana. A primeira é a recusa da negritude. ${ }^{*}$ Formulando-a de forma simples, populações negras existiram desde a era colonial em todos os vice-reinados. O fato de que essas comunidades não sobreviveram no Cone Sul depois do século XIX indica que a fundação desses Estados-nações dependeu de um processo de esquecimento e reinvenção, não muito diferente daquele da repressão na psicanálise. Como se deve abordar o fato de Mistral louvar os negros publicamente e desprezá-los no espaço privado? Será que os pesquisadores deveriam simplesmente negligenciar o fato como desimportante, em consideração à posição da Mistral defensora de povos indígenas, mulheres e crianças? É algo extraordinário que Mistral tenha agido como se nunca tivesse ouvido falar de populações negras na América Latina antes de suas viagens ao Caribe em 1930 e que tenha reagido ao sujeito negro com atitudes brancas estereotipadas: ansiedade, sexualização e patologização. A famosa fórmula freudiana da recusa descreve perfeitamente essa operação. Mistral sabia que havia latino-americanos negros, mas para ela latino-americanos eram índios, e ponto final. As operações discursivas do latino-americanismo obliteraram o sujeito negro da representação estética e política.

A segunda operação presente na escrita de Mistral é a cumplicidade da linguagem da diversidade com as práticas do pensamento supremacista branco. ${ }^{70}$ Alguns críticos negligenciam a narrativa de Mistral sobre a morte de Yin Yin como mera "loucura", ou como desvio "pessoal". A genealogia da mestiçagem em seu pensamento demonstra, porém, uma bifurcação entre o que Mistral declarava publicamente e o que ela acreditava na intimidade. As confidências trocadas em meios menos formais, tais como correspondências e entrevistas, não eram, é claro, totalmente privadas; sua circulação dentro de um seleto grupo de intelectuais e leitores de periódicos sugere, para dizer o mínimo, uma ambivalência racial pública. $O$ grito de Mistral dando conta do assassinato racial de Yin Yin, embora certamente afetado pela mágoa e talvez pela 
culpa, não pode ser atribuído apenas a esses sentimentos. Isto é, é possível estar magoada ou mentalmente instável e também ser racista. Se alguns críticos diminuíram a gravidade das acusações de Mistral, dadas as circunstâncias extremas que as motivaram, eles apagaram outro dado extremo: a caracterização que Mistral construiu dos sujeitos negros nacionais.

A terceira operação é o papel da queerness de Mistral em seu nacionalismo racializado. Mistral tornou a nação queer, com certeza, porém essa atitude aprimorou não apenas a heteronormatividade, mas também o silencioso projeto racial latino-americano. Sua mágoa maternal e quaisquer alusões a sentimentos pessoais podem complementar, não obscurecer, a análise de seu discurso maternal nacionalista e do quanto ele tem a ver com a garantia da "reprodução da nação". Enquanto o discurso oficial de Mistral celebra as qualidades abstratas de mãe e filhos, algumas de suas outras falas não deixam dúvida de que algumas mulheres nunca deveriam ser mães nesse sentido e que seus filhos nunca seriam considerados filhos da América Latina. Não há alianças necessárias, garantidas ou previsíveis entre pessoas sexualmente oprimidas e pessoas racialmente oprimidas. Mistral, enquanto queer, mas também sua queerness projetada nacionalmente ajudaram a articular o discurso do Estado sobre a reprodução da nação, um exemplo do "direito à vida" proposto por Foucault no âmbito do biopoder. Entre uma identidade sexual proibida e uma identidade nacional racista, permanecem as contradições de Mistral como mulher-raça: proclamando os dogmas do latino-americanismo, trabalhando no interior de suas formulações heteronormativas e de gênero, e reproduzindo o Estado racista e homofóbico.

Nota

Agradeço a Ann Pellegrini, que me estimulou a mandar este artigo ao GLQ. Sinceros agradecimentos a Carlyn Dinshaw, David M. Halperin e ao anônimo revisor da GLQ por sua leitura crítica e estimulante. Sou muito grata aos que assistiram a palestras minhas feitas a partir deste artigo, e aos colegas que me convidaram para elas. Agradecimentos especiais a Lisa Duggan e aos membros do Grupo de Queer Studies da Universidade de Nova York pelo seu entusiasmo contagiante. Agradeço ainda a Amy Reading pelo diálogo editorial. E mantenho profunda gratidão a Gayatri Patnaik pelas muitas horas que dedicou a ler e comentar este artigo. Ela me ajudou a articular minha pesquisa e minhas idéias com mais clareza, eloqüência e elegância. A ela eu dedico este artigo.

\section{Referências bibliográficas}

ARREDONDO, E. Fernández. "Al margen del 'incidente' con Gabriela Mistral”. Diario de la Marina, Cuba, 13 abr. 1930.

ENCINA, Francisco Antonio. Nuestra inferioridad económica: sus causas, sus consecuencias. Santiago: Editorial Universitaria, 1978 [1911]. 
FIOL-MATTA, Licia. "The 'Schoolteacher of America': Gender, Sexuality, and Nation in Gabriela Mistral." In: BERGMANN, Emilie L., and SMITH, Paul Julian (eds.). ¿Entiendes? Queer Readings, Hispanic Writings. Durham: Duke University Press, 1995. p. 201-229.

Schooling Sexuality: The State and Gabriela Mistral. Durham: Duke University Press, no prelo.

FUSS, Diana. Identification Papers. New York: Routledge, 1995.

GRAHAM, Richard (ed.). The Idea of Race in Latin America, 1870-1940. Austin: University of Texas Press, 1990.

HANCHARD, Michael George. "Racial Democracy: Hegemony, Brazilian Style." In: Orpheus and Power: The Movimento Negro of Rio de Janeiro and São Paulo, Brazil, 1945-1988. Princeton: Princeton University Press, 1994. p. 43-74.

HELG, Aline. "Race in Argentina and Cuba, 1880-1930: Theory, Policy, and Popular Reaction." In: GRAHAM, Richard (ed.). The Idea of Race in Latin America, 1870-1940. Austin: University of Texas Press, 1990. p. 37-69.

HIRIART, Rosario (ed.). Cartas a Lydia Cabrera: correspondencia inédita de Gabriela Mistral y Teresa de la Parra. Madrid: Torremozas, 1988.

HORAN, Elizabeth Rosa. "Gabriela Mistral." In: FOSTER, David William (ed.). Latin American Writers on Gay and Lesbian Themes: A Bio-Critical Sourcebook. Westport, Conn.: Greenwood, 1994.

"Santa Maestra Muerta: Body and Nation in Portraits of Gabriela Mistral." Taller de letras, n. 25, 1997. p. 21-43.

KAMINSKY, Amy. "Essay, Gender, and Mestizaje: Victoria Ocampo and Gabriela Mistral." In: The Politics of the Essay: Feminist Perspectives. JOERES, Ruth-Ellen Boetcher, and MITTMAN, Elizabeth (eds.). Bloomington: Indiana University Press, 1993.

KNIGHT, Alan. "Racism, Revolution, and Indigenismo: Mexico, 1910-1940." In: GRAHAM, Richard (ed.). The Idea of Race in Latin America, 1870-1940. Austin: University of Texas Press, 1990. p. 71-113.

LAVRIN, Asunción. Women, Feminism, and Social Change in Argentina, Chile, and Uruguay, 1890-1940. Lincoln: University of Nebraska Press, 1995.

MARCHANT, Patricio. "Desolación". In: Una palabra cómplice. OLEA, Raquel, and FARIÑA, Soledad (eds.). Santiago: Cuarto Propio, 1996. p. 60-61.

MISTRAL, Gabriela. "A la mujer mexicana". In: SCARPA, Roque Esteban (ed.). Lecturas para mujeres: destinadas a la enseñanza del lenguaje. Madrid: Godoy, 1924. p. 123-135. "El tipo del indio americano". In: SCARPA, Roque Esteban (ed.). Gabriela anda por el mundo. Santiago: Andrés Bello. 1978a.

"La pampa argentina". In: SCARPA, Roque Esteban (ed.). Gabriela anda por el mundo. Santiago: Andrés Bello, 1978b. p. 51-53.

. "Primer recuerdo de Isadora Duncan". In: SCARPA, Roque Esteban (ed.). Gabriela anda por el mundo. Santiago: Andrés Bello, 1978c.

. "Recado de una maestra argentina". In: SCARPA, Roque Esteban (ed.). Magisterio y niño. Santiago: Andrés Bello, 1979a. p. 124-135.

. "Madrinas de lectura". In: SCARPA, Roque Esteban (ed.). Magisterio y niño. Santiago:

Andrés Bello, 1979b. p. 98-100.

. "El folklore argentino". In: SCARPA, Roque Esteban (ed.). Magisterio y niño. Santiago: Andrés Bello, 1979c. "Imagen y palabra en la educación". In: SCARPA, Roque Esteban (ed.). Magisterio y niño. Santiago: Andrés Bello, 1979d. . Antología mayor: cartas. Santiago: Cochrane, 1992. 
"Sobre la mujer chilena". In: QUEZADA, Jaime (ed.). Escritos políticos. Santiago: Fondo de Cultura Económica, 1994. p. 61-65

MOLLOY, Sylvia. "The Politics of Posing." In: MOLLOY, Sylvia, and IRWIN, Robert McKee (eds.). Hispanisms and Homosexualities. Durham: Duke University Press, 1998.

"Disappearing Acts: Reading Lesbian in Teresa de la Parra." In: BERGMANN, Emilie, and SMITH, Paul Julian (eds.). ¿Entiendes? Durham, NC: Duke UP, 1995. p. 230-256.

MONTECINOS, Sonia. Madres y huachos: alegorías del mestizaje chileno. Santiago: Sudamericana, 1991.

MORALES, Juan Villegas "El estado como mecenas: el caso de Gabriela Mistral". In:

Estudios sobre la poesía chilena. Santiago: Nascimento, 1980.

NOVO, Salvador. "Ventana: con Gabriela Mistral I". Novedades. Mexico City: Stylo, 1948. . La estatua de sal. Mexico City: Consejo Nacional para la Cultura y las Artes, 1998. Ed. Carlos Monsiváis.

OMI, Michael, and WINANT, Howard. Racial Formation in the United States: From the 1960s to the 1990s. New York: Routledge, 1994.

PALACIOS, Néstor. Raza chilena. Santiago: Antiyal, 1986.

PIZARRO, Ana. "Mistral, ¿qué modernidad?" In: LILLO, Gastón, and RENART, Guillermo (ed.). Re-leer hoy a Gabriela Mistral: mujer, literatura y sociedad. Ottawa: University of Ottawa Press; Santiago: Editorial de la Universidad de Santiago, 1997.

"POLÉMICA genera supuesta maternidad de Mistral". El Mercurio, 7 nov. 1999.

QUEZADA, Jaime (ed.). Escritos políticos. Santiago: Fondo de Cultura Económica, 1994. Prefácio de Gabriela Mistral.

ROSALES, Vicente Pérez. Recuerdos del pasado (1814-1860). Buenos Aires: Francisco de Aguirre, 1970 [1882].

SAAVEDRA, Luis Vargas (comp.). Tan de usted: epistolario de Gabriela Mistral con Alfonso Reyes. Santiago: Hachette/Editorial de la Universidad Católica de Chile, 1991.

SAAVEDRA, Luis Vargas (ed.). Vuestra Gabriela: cartas inéditas de Gabriela Mistral a los Errázuriz Echenique y Tomic Errázuriz. Santiago: Zig-Zag, 1995.

SANDOVAL SÁNCHEZ, Alberto. "Hacia una lectura del cuerpo de mujer". In: OLEA, Raquel, and FARIÑA, Soledad (eds.). Una palabra cómplice. Santiago: Cuarto Propio, 1996. p. 139-151.

SANTELICES, Isauro. Mi encuentro con Gabriela Mistral. Santiago: Pacífico, 1972.

SCARPA, Roque Esteban. La desterrada en su patria: Gabriela Mistral en Magallanes, 19181920. Santiago: Nascimento, 1977. 2 v.

SCHNEIDER, Luis Mario. Gabriela Mistral: Itinerario veracruzano. Xalapa: Biblioteca de la Universidad Veracruzana, 1991.

SKIDMORE Thomas E. "Racial Ideas and Social Policy in Brazil, 1870-1940." In: GRAHAM, Richard (ed.). The Idea of Race in Latin America, 1870-1940. Austin: University of Texas Press, 1990. p. 7-36.

. Black into White: Race and Nationality in Brazilian Thought. Durham: Duke University Press, 1993.

“'SOBRINO' de Gabriela Mistral era en realidad su hijo”. El Mercurio, Santiago, 6 nov. 1999.

STEPAN, Nancy Leys. The "Hour of Eugenics": Race, Gender, and Nation in Latin America. Ithaca: Cornell University Press, 1991.

STOLER, Ann Laura. Race and the Education of Desire: Foucault's "History of Sexuality" and the Colonial Order of Things. Durham: Duke University Press, 1995.

TEITELBOIM, Volodia. Gabriela Mistral pública y secreta: truenos y silencios en la vida del primer Nobel latino-americano. Santiago: BAT, 1991.

VASCONCELOS, José. La raza cósmica. Mexico City: Espasa-Calpe, 1996. 
[Recebido em fevereiro de 2004 e aceito para publicação em março de 2004]

"Race Woman": Reproducing the Nation in Gabriela Mistral

Abstract: This article unmasks Gabriela Mistral's fiercely claimed public position, as the champion of the indigenous peoples of Latin America, by arguing that in her intimacy her position was absolutely opposed to any public nonnormative sexual stance. The author proposes three critical operations for the reading of Mistral's work, regarding the subject of the Latin American "race": the disavowal of blackness (Mistral responds to it with anxiety, sexualization, and pathologization, i.e., stereotypical white responses), the complicity of the language of diversity in the practices of white supremacist thinking (which is made clear in her correspondence), and the role played by Mistral's queerness in her racialized nationalism (her queerness helped improve heteronormativity and the Latin Americanist racial project).

Key Words: Gabriela Mistral, queer, sexual normativity, race, indigenous peoples.

Tradução de Luis Felipe Soares

Este artigo já havia sido publicado como "Race-Woman: Reproducing the Nation in Gabriela Mistral". GLQ: A Journal of Lesbian and Gay Studies, 6.4, 2000: 491-527. A publicação da tradução foi feita com autorização da autora.

264 Estudos Feministas, Florianópolis, 13(2): 227-264, maio-agosto/2005 
O arquivo disponível sofreu correções conforme ERRATA publicada no Volume 13 Número 3 da revista. 